\title{
A noble gas technique for the identification of mantle and crustal materials and its application to the Kuroko deposits
}

\author{
Bin Li and OLIVER K. MANUEL \\ Department of Chemistry, University of Missouri, Rolla, MO 65401, U.S.A.
}

(Received September 17, 1993; Accepted February 3, 1994)

\begin{abstract}
In this paper, we propose to use noble gas abundance patterns and isotopic ratios to distinguish between mantle and crustal origin of different types of geological samples. The Kuroko deposits were selected as our first application.

The mantle, the crust, and the atmosphere have different noble gas abundance patterns and isotopic ratios. The relative abundances of $\mathrm{He}$ and $\mathrm{Ne}$ are high in the mantle. The heavy noble gases- $\mathrm{Ar}, \mathrm{Kr}$ and $\mathrm{Xe}-$ are enriched in seawater and seawater-related products. The ${ }^{3} \mathrm{He} /{ }^{4} \mathrm{He}$ and ${ }^{129} \mathrm{Xe} /{ }^{130} \mathrm{Xe}$ isotopic ratios are usually higher for the mantle than for the atmosphere and the crust. These properties may be used to distinguish the source of geological samples. In this work, the abundances of $\mathrm{Ne}, \mathrm{Ar}$ and $\mathrm{Xe}$ and the isotopic ratios of $\mathrm{Ar}$ and $\mathrm{Xe}$ were determined for 18 Kuroko ore samples. The concentrations of $\mathrm{Ne}, \mathrm{Ar}$, and $\mathrm{Xe}$ in the Kuroko ores are like those of magmatic rocks. The abundance pattern of noble gases in the Kuroko ores parallels that of mantle-derived samples. Distribution coefficients of noble gases were calculated from two submarine diabase samples that equilibrated with seawater. Assuming these solid-liquid distribution coefficients can be applied to Kuroko and other magmatic rocks, we calculated the noble gas concentrations of their hypothetical source fluids. The results were used to compute the relative contributions of magmatic source fluid and seawater to the Kuroko ore-forming fluid. Based on Xe data, the relative contributions of magmatic source and seawater to the Kuroko ore fluid are calculated to be $75 \%$ and $25 \%$, respectively.
\end{abstract}

\section{INTRODUCTION}

In many disciplines of Earth sciences, identification of the material source of rock and ore samples may elucidate their formation. The distinction between mantle and crustal sources may be critical because the mantle and the crust are two major units of the Earth from which samples are derived. Isotopic analyses of $\mathrm{H}, \mathrm{C}, \mathrm{O}, \mathrm{S}, \mathrm{Pb}$, $\mathrm{Sr}$, and $\mathrm{Nd}$ have been used to differentiate reservoirs of geological interests (Hoefs, 1987; Faure, 1986; Faure and Powell, 1972; Doe, 1970; Valley et al., 1986; DePaolo, 1988). Many noble gas studies have focused on meteorites and lunar samples, but sufficient noble gas isotopic data have also been accumulated on terrestrial materials to permit the designation of characteristic abundance and isotopic signatures for the crust, the mantle, and the atmosphere (Ozima and Alexander, 1976; Manuel and Sabu, 1981; Allègre et al., 1987). In this study, we analyzed noble gases in an attempt to determine the contribution of the mantle and the crust to the Japanese Kuroko deposits.

Isotopic and elemental ratios of noble gases in MORBs (Mid-Ocean Ridge Basalts), oceanic plumes, continental hot spots and common terrestrial rocks have made possible a generalization about the composition of major terrestrial reservoirs (Ozima and Podosek, 1983; Allègre et al., 1987). Ozima and Alexander (1976) identified three different abundance patterns of the terrestrial noble gases. Type 1 is the pattern of noble gases in seawater, sedimentary rocks, and other samples that equilibrated with seawater. Type 2 is the pattern observed in typical mantle samples, several of which show ${ }^{129} \mathrm{Xe}$ anomaly. Type 3 represents 
some unusual terrestrial samples. On the basis of different isotopic ratios of noble gases, Allègre and Staudacher (1986) and Allègre et al. (1987) divided the Earth into four reservoirs: atmosphere, continental crust, upper mantle, and lower mantle. They summarize the available data on terrestrial samples and noted characteristic isotopic signatures of noble gases for each of these reservoirs. We propose to use the abundance patterns and isotopic ratios as a new noble gas technique to differentiate between mantle and crustal sources for terrestrial samples. Here we demonstrate the utility of this technique by identifying the roles of magmatic and seawater sources for the ore-forming fluid of the Kuroko deposits. All references to the mantle in the rest of this paper refer to the upper mantle as defined by Allègre and Staudacher (1986) and Allègre et al. (1987).

The Kuroko deposit of Japan is a major type of massive sulfide deposit. Our current understanding of massive sulfide deposits and other related deposits comes from the extensive studies of the Kuroko deposits (Ishihara et al., 1974; Franklin et al., 1981; Ohmoto and Skinner, 1983; and the collection of papers in a special issue of Mining Geology, Vol. 28, No. 150, 1978). Since the 1960 's, many deposits have been reclassified as massive sulfide deposits and new deposits have been discovered throughout the world by the knowledge gained from Kuroko study. Before the 1970's, Kuroko investigations focused on the mineralogy and petrology of individual deposits. These were carried out mainly by Japanese researchers (Ishihara et al., 1974). Later, there were two international efforts to study the genesis of these deposits. A U.S.-Japan joint project beginning in 1974 resulted in a special issue of Mining Geology (Vol. 28, No. 150) in 1978. A U.S.-JapanCanada cooperative research project on the genesis of the Kuroko deposits began in 1978. This project utilized compositional, geological, petrographic, isotopic, and fluid inclusion techniques. The results were published as Economic Geology Monograph 5 (Ohmoto and Skinner, 1983).

Although the Kuroko deposits are the most studied massive sulfide deposits, their genesis has been controversial since the 1920 's. It is generally believed that the Kuroko deposits formed on sea floor depressions through chemical precipitation. As the hot, ore-forming fluid came upward near the sea floor, it was diluted by the cold seawater. According to this model, precipitation of oreforming minerals, such as sphalerite, galena, chalcopyrite, and pyrite, occurred when the temperature dropped as the hot ore-forming fluid came into contact with the cold seawater (Tatsumi and Watanabe, 1971; Ishihara et al., 1974; Lambert and Sato, 1974; Ohmoto and Skinner, 1983). Currently there are two major Kuroko genetic models. They differ mainly in the source of the ore-forming fluid. Some believe that the ore fluid is seawater (Ohmoto and Rye, 1974; Pisutha-Arnond and Ohmoto, 1983; Ohmoto et al., 1983), while others think there is substantial contribution from magmatic sources (Urabe and Sato, 1978; Ishihara and Sasaki, 1978; Farr and Scott, 1981; Sawkins, 1986, 1990). Still others hold that the ore fluid can be formed completely from magmatic fluid (Urabe, 1987).

We measured the concentration and isotopic composition of noble gases in the Kuroko ores to seek information on the source of the ore-forming fluid. If mantle components can be identified, this would suggest contribution from a magmatic source. If not, this would automatically support the model of seawater as the sole source for the ore-forming fluid.

\section{The Noble Gas Technique}

It is generally agreed that the mantle and the crust exchange materials. Mantle materials come to the crust through volcanos and magmatic intrusions beneath the Earth's surface, such as the magmatic eruptions that form mid-ocean ridges. Likewise, crustal materials enter the mantle through the subduction of oceanic plates, typically at island arc areas. Mantle materials may also be contaminated by crustal materials as they approach the surface. Although studies on the genesis of samples seek the identification of the material source, it is possible that the results will indicate that more than 
one source was involved in the formation of the sample.

Noble gas analysis provides two means to differentiate mantle materials from crustal ones. The first is the abundance. The mantle and the crust have different absolute noble gas abundances and different abundance patterns (Ozima and Alexander, 1976). Of special interest for the Kuroko deposits are the pronounced differences in the noble gas abundance pattern for mantle materials and that for seawater and seawater-related products. The latter are enriched in heavy noble gases, $\mathrm{Kr}$ and $\mathrm{Xe}$, while upper mantle materials are enriched in $\mathrm{Ne}$ and primordial helium. The second is isotopic composition. Materials from the upper mantle usually have high ${ }^{3} \mathrm{He} /{ }^{4} \mathrm{He},{ }^{40} \mathrm{Ar} /{ }^{36} \mathrm{Ar}$, and ${ }^{129} \mathrm{Xe} /{ }^{130} \mathrm{Xe}$ ratios. Differences in both the abundance pattern and the isotopic compositions provide an internal check which makes the noble gas technique more reliable than others that offer only one elemental or isotopic ratio.

\section{Noble gas abundances}

The absolute abundances of noble gases in mantle-derived samples are several orders-ofmagnitude less than those in seawater or sedimentary products, especially for the heavy gases. The average of several analyses of seawater from Pacific and Indian oceans is $5.3 \times 10^{-8} \mathrm{ccSTP} / \mathrm{g}$ for ${ }^{84} \mathrm{Kr}$; and $4.5 \times 10^{-10} \mathrm{ccSTP} / \mathrm{g}$ for ${ }^{130} \mathrm{Xe}$ (Allègre et al., 1987). The concentrations of ${ }^{84} \mathrm{Kr}$ and ${ }^{130} \mathrm{Xe}$ in MORB glasses are extremely low, only $3.2 \times 10^{-12}$ $\mathrm{ccSTP} / \mathrm{g}$ and $6.9 \times 10^{-14} \mathrm{ccSTP} / \mathrm{g}$, respectively
(Allègre et al., 1987). Table 1 gives the abundances of noble gases in air, in MORB and Loihi samples from the lower mantle, in seawater, and in some products of seawater sedimentation. As can be seen from the table, the sea floor sediments, old oceanic crust and the Fig Tree shale all show strong enrichment in the heavy gases. This progressive enrichment of heavy gases in sediments (Canalas et al., 1968; Podosek et al., 1980) and the great difference between the abundances of $\mathrm{Kr}$ and $\mathrm{Xe}$ in seawater and in the mantle can be used to distinguish mantle from seawater-related sources.

Figure 1 shows the three types of terrestrial noble gases identified by Ozima and Alexander (1976). The fractionation factor, $F^{m}$, on the ordinate is:

$$
F^{m}=\left({ }^{m} \mathrm{X} /{ }^{36} \mathrm{Ar}\right)_{s} /\left({ }^{m} \mathrm{X} /{ }^{36} \mathrm{Ar}\right)_{\text {air }}
$$

where $s$ is sample and ${ }^{m} \mathrm{X}$ is a noble gas isotope with mass $m$. The Type 1a pattern is observed in sedimentary rocks and seawater related products (Fig. 1a). The Type lb pattern is observed in natural gases and waters (Fig. 1b). These may reflect equilibrium of atmospheric noble gases with seawater and submarine solids. The solid line in Type $1 \mathrm{~b}$ shows the pattern established by the adsorption of atmospheric gases into water at $20^{\circ} \mathrm{C}$. The Type 2 pattern (Fig. 1c) is characteristic of mantle-derived samples. Glassy submarine basalts (Dymond and Hogan, 1973) and two other terrestrial samples which show high ${ }^{129} \mathrm{Xe}$ excess

Table 1. Noble gas abundances of different reservoirs of geological interest (Allègre et al., 1987)

\begin{tabular}{lccccc}
\hline & $\begin{array}{c}{ }^{3} \mathrm{He} \\
\left(10^{-10} \mathrm{~cm}^{3} / \mathrm{g}\right)\end{array}$ & $\begin{array}{c}{ }^{20} \mathrm{Ne} \\
\left(10^{-10} \mathrm{~cm}^{3} / \mathrm{g}\right)\end{array}$ & $\begin{array}{c}{ }^{36} \mathrm{Ar} \\
\left(10^{-10} \mathrm{~cm}^{3} / \mathrm{g}\right)\end{array}$ & $\begin{array}{c}{ }^{84} \mathrm{Kr} \\
\left(10^{-12} \mathrm{~cm}^{3} / \mathrm{g}\right)\end{array}$ & $\begin{array}{c}130 \mathrm{Xe} \\
\left(10^{-14} \mathrm{~cm}^{3} / \mathrm{g}\right)\end{array}$ \\
\hline Atmosphere & 0.00014 & 348 & 663 & 1,370 & 740 \\
MORB & 2.66 & 1.7 & 0.7 & 3.2 & 6.9 \\
Loihi & 0.001 & 5.8 & 8.6 & 20.2 & 15.9 \\
Deep Seawater $_{\text {Fig Tree Shale }}{ }^{a}$ & 0.00063 & 1,740 & 12,700 & 52,600 & 45,100 \\
Old Oceanic Crust & $0.59^{b}$ & 10.2 & 5,900 & 59,000 & 230,000 \\
Seafloor Sediments & 0.001 & 1.0 & 31.9 & 164 & 738 \\
\hline
\end{tabular}

${ }^{a}$ Canalas et al. (1968).

${ }^{b}$ Calculated from ${ }^{4} \mathrm{He}$ assuming atmospheric ratio. 

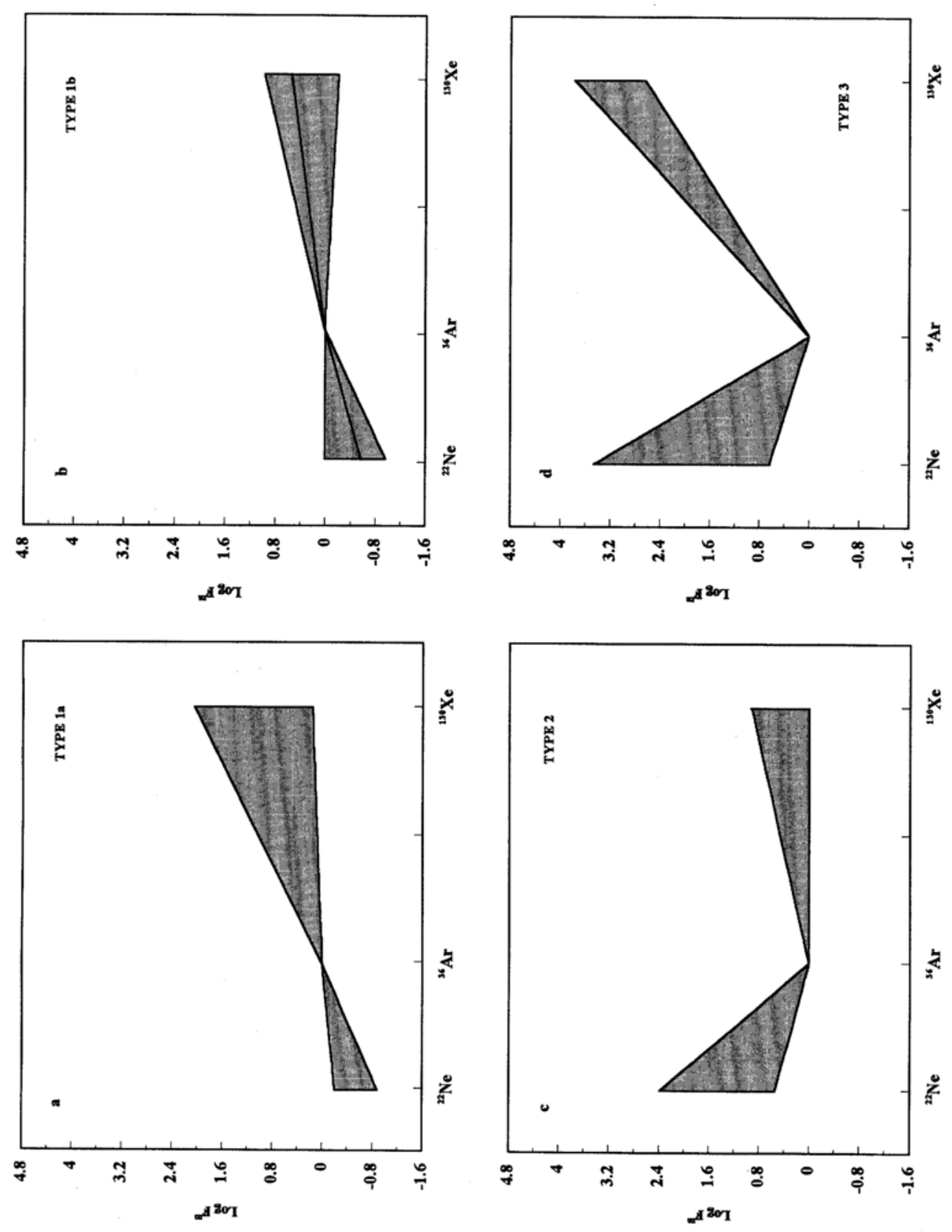

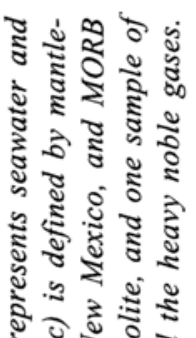
幺

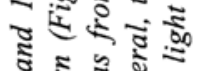
๑ ฐ कृष

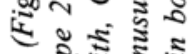
2.5

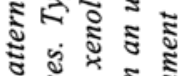
ป ป $-\infty, \frac{5}{2}$

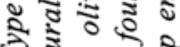

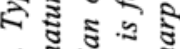
में ปั है ล. จ ชै है के จ

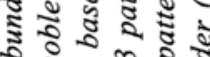
ह ते क

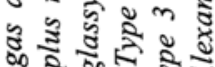

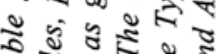
รัปส

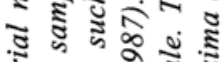
ป ป ป

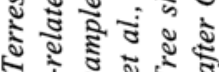

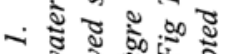

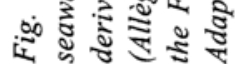


(Hennecke and Manuel, 1975a, b, c) were originally used to obtain this pattern. We have also included the MORB data of Allègre et al. (1987) in constructing Fig. 1c. The Type 3 noble gas pattern (Fig. 1d) shows a sharp enrichment in both light $(\mathrm{Ne})$ and heavy $(\mathrm{Kr}, \mathrm{Xe})$ noble gases. It represents some unusual terrestrial samples, Fig Tree shale and thucholite (Canalas et al., 1968; Bogard et al., 1965).

The noble gas isotopes used in the abundance pattern, ${ }^{22} \mathrm{Ne},{ }^{36} \mathrm{Ar},{ }^{84} \mathrm{Kr}$, and ${ }^{130} \mathrm{Xe}$, are primordial components, except for an occasional small contribution to ${ }^{84} \mathrm{Kr}$ from fission of ${ }^{238} \mathrm{U}$ and traces of radiogenic ${ }^{130} \mathrm{Xe}$ from the extremely rare double-beta decay of ${ }^{130} \mathrm{Te}$. Although noble gas compounds have been synthesized in the laboratory, they are not found in nature. Thus, the different abundance patterns are not the results of chemical properties. This makes the noble gas abundance pattern a useful geochemical tool, similar to the REE pattern.

Type 1 and Type 2 noble gas patterns shown in Fig. 1 are of special interest because they show distinct patterns for these elements in mantle and crustal sedimentary materials. The main difference is the Ne abundance. Sedimentary samples show a depletion of $\mathrm{Ne}$ and a gradual enrichment for $\mathrm{Kr}$ and $\mathrm{Xe}$ relative to the noble gases in air. The mantle type noble gas pattern shows a strong enrichment in $\mathrm{Ne}$ with $\mathrm{Kr}$ and $\mathrm{Xe}$ abundances only slightly above those of air. These two distinct abundance patterns can be used to distinguish the contribution of mantle and seawater to a sample's noble gas inventory.

\section{Noble gas isotopic composition}

Allègre et al. (1987) and Allègre and Staudacher (1986) tabulated distinguishing isotopic ratios of noble gases in the atmosphere, continental crust, upper mantle (MORB), and lower mantle (Loihi Seamount). Table 2 shows their results. It can be seen that the upper mantle sample (MORB) has several distinct noble gas isotopic ratios, such as ${ }^{3} \mathrm{He} /{ }^{4} \mathrm{He},{ }^{20} \mathrm{Ne} /{ }^{22} \mathrm{Ne}$, and ${ }^{129} \mathrm{Xe} /{ }^{130} \mathrm{Xe}$. Values of ${ }^{21} \mathrm{Ne} /{ }^{22} \mathrm{Ne},{ }^{40} \mathrm{Ar} /{ }^{36} \mathrm{Ar}$, and ${ }^{136} \mathrm{Xe} /{ }^{130} \mathrm{Xe}$ for MORB overlap those of the continental crust. However, the range of values for MORB is usually narrower than those for the crust. These isotopic features are useful in identifying mantle and crustal materials.

The helium isotopic ratio The mantle and crustal values of the ${ }^{3} \mathrm{He} /{ }^{4} \mathrm{He}$ ratio are widely separated. Average of the ${ }^{3} \mathrm{He} /{ }^{4} \mathrm{He}$ ratio are $0.004 \times 10^{-5}, 0.14$ $\times 10^{-5}, 1.2 \times 10^{-5}$ and $4.0 \times 10^{-5}$ for the crust, the air, upper mantle, and lower mantle, respectively (Staudacher et al., 1986; Allègre and Staudacher, 1986; Allègre et al., 1987). This is attributed to a relatively high concentration of primordial helium in the lower mantle and to a relatively high content of radiogenic helium from $\alpha$-decay of $U$ and $T h$ in the crust. The ${ }^{3} \mathrm{He} /{ }^{4} \mathrm{He}$ ratio is therefore a sensitive indicator of these sources.

However, it should be noted that the above statement is true only for relatively young samples ( $\$ 10^{8}$ years). Radiogenic ${ }^{4} \mathrm{He}$ from the decay of uranium and thorium may completely dominate the trapped helium for samples older than about $10^{8}$ years.

The neon isotopes $\mathrm{High}{ }^{20} \mathrm{Ne} /{ }^{22} \mathrm{Ne}$ ratios have been observed in mantle-derived materials (Ozima

Table 2. Noble gas isotopic ratios of four terrestrial reservoirs ${ }^{a}$

\begin{tabular}{lcrrr}
\hline & \multicolumn{1}{c}{ Crust } & \multicolumn{1}{c}{ MORB } & \multicolumn{1}{c}{ Loihi } & Atmosphere \\
\hline${ }^{3} \mathrm{He} /{ }^{4} \mathrm{He}$ & $4.0 \mathrm{E}-08$ & $1.2 \mathrm{E}-05$ & $4.0 \mathrm{E}-05$ & $1.4 \mathrm{E}-06$ \\
${ }^{20} \mathrm{Ne} /{ }^{22} \mathrm{Ne}$ & $9-12$ & $10-13$ & $?$ & 9.8 \\
${ }^{21} \mathrm{Ne} /{ }^{22} \mathrm{Ne}$ & $0.03-0.7$ & $0.03-0.07$ & $?$ & 0.029 \\
${ }^{40} \mathrm{Ar} /{ }^{36} \mathrm{Ar}$ & $2,000-140,000$ & $13,000-28,000$ & $360-425$ & 296 \\
${ }^{129} \mathrm{Xe} /{ }^{130} \mathrm{Xe}$ & 6.48 & $6.71-7.36$ & $6.46-6.48$ & 6.48 \\
${ }^{136} \mathrm{Xe} /{ }^{130} \mathrm{Xe}$ & $2.26-7.92$ & $2.25-2.55$ & $2.16-2.21$ & 2.17 \\
\hline
\end{tabular}

${ }^{a}$ Data from Allègre and Staudacher (1986) and Allègre et al. (1987). 
and Podosek, 1983; Staudacher et al., 1986; Honda et al., 1991, 1993). Allègre et al. (1987) note that values of the ${ }^{20} \mathrm{Ne} /{ }^{22} \mathrm{Ne}$ ratio are $9.8 \mathrm{in}$ air, $9-10.2$ in the crust, and $10-13$ in the mantle. For the ${ }^{21} \mathrm{Ne} /$ ${ }^{22} \mathrm{Ne}$ ratio, the value is $0.03-0.07$ in the mantle and $0.03-0.7$ in the crust. Therefore, neon isotopes can also be used to identify the source of materials.

The xenon isotopes Xenon has nine stable isotopes. The primordial xenon isotopes were produced in stars by the r-, p-, and s-processes (Burbidge et al., 1957; Clayton, 1975). Xenon also has a radiogenic component from the decay of extinct ${ }^{129}$ I (Reynolds, 1960; Jeffrey and Reynolds, 1961) and a fissiogenic component from the spontaneous fission of ${ }^{238} \mathrm{U}$ (Wetherill, 1953) and ${ }^{244} \mathrm{Pu}$ (Rowe and Kuroda, 1965; Fields et al., 1966). We use ${ }^{130} \mathrm{Xe}$ as the reference isotope because it is shielded by ${ }^{130} \mathrm{Te}$ from production by fission.

The ${ }^{129} \mathrm{Xe} /{ }^{130} \mathrm{Xe}$ ratio is 6.48 for air, the crust and seawater. However, the early decay of ${ }^{129} \mathrm{I}$ resulted in a range of ${ }^{129} \mathrm{Xe} /{ }^{130} \mathrm{Xe}$ values, $6.6-7.4$, in $\mathrm{CO}_{2}$, volcanic xenoliths containing fluid $\mathrm{CO}_{2}$, MORB and other samples from the upper mantle. Staudacher and Allègre (1982) reported ${ }^{129} \mathrm{Xe}$ excesses accompanied by a typical mantle ${ }^{3} \mathrm{He} /{ }^{4} \mathrm{He}$ ratio in MORB glasses from East Pacific Rise, Galapagos Rise, Atlantic Ocean and Indian Ocean. However, not all MORB samples have excess ${ }^{129} \mathrm{Xe}$. Some of these samples have a high ${ }^{3} \mathrm{He} /{ }^{4} \mathrm{He}$ ratio but the ${ }^{129} \mathrm{Xe} /{ }^{130} \mathrm{Xe}$ ratio of air. Crustal contamination from seawater or sedimentary rocks may explain this observation. Since seawater and sediments have high concentration of xenon compared to mantle samples, a few per cent of contamination from these crustal material can easily mask the relatively small $(<14 \%)$ excess of ${ }^{129} \mathrm{Xe}$ found in some mantle materials. Manuel and Sabu (1981) and Allègre and Staudacher (1986) have suggested that high values of ${ }^{3} \mathrm{He} /{ }^{4} \mathrm{He}$ are characteristic of noble gases in the undepleted, lower mantle and that high values of ${ }^{129} \mathrm{Xe} /{ }^{130} \mathrm{Xe}$ are characteristic of noble gases in the upper, highlydepleted mantle. According to this view, the occurrence of high ${ }^{3} \mathrm{He} /{ }^{4} \mathrm{He}$ ratios in MORB samples is caused by the leakage of primordial helium from the lower mantle.

The ${ }^{136} \mathrm{Xe} /{ }^{130} \mathrm{Xe}$ ratio for the atmosphere and seawater is 2.17 . Some geological samples show a variation in this ratio due to spontaneous fission of ${ }^{238} \mathrm{U}$. The MORB glasses show values of ${ }^{136} \mathrm{Xe} /$ ${ }^{130} \mathrm{Xe}=2.25-2.55$; the crustal range is $2.2-7.9$, depending on the concentration of uranium and the age of the samples. The ${ }^{134} \mathrm{Xe} /{ }^{130} \mathrm{Xe}$ ratio shows the same trend as the ${ }^{136} \mathrm{Xe} /{ }^{130} \mathrm{Xe}$ ratio. Although there is overlap between the mantle and the crustal values of ${ }^{136} \mathrm{Xe} /{ }^{130} \mathrm{Xe}$, there is no overlap between seawater and mantle values of this ratio. Thus, the ${ }^{136} \mathrm{Xe} /{ }^{130} \mathrm{Xe}$ ratio may help resolve the origin of the Kuroko ores.

In summary, the noble gas technique includes relative abundances and several isotopic ratios, including ${ }^{3} \mathrm{He} /{ }^{4} \mathrm{He},{ }^{20} \mathrm{Ne} /{ }^{22} \mathrm{Ne},{ }^{129} \mathrm{Xe} /{ }^{130} \mathrm{Xe},{ }^{134} \mathrm{Xe} /$ ${ }^{130} \mathrm{Xe}$ and ${ }^{136} \mathrm{Xe} /{ }^{130} \mathrm{Xe}$. These multiple distinguishing parameters permit internal checking which make the technique more reliable. Although noble gases are rare, they are ubiquitous. This means that the technique can be applied to most geological samples without being limited to specific types of rocks or minerals. The gaseous nature of the noble gases can also be considered an advantage. The noble gas method identifies mantle materials by excess ${ }^{3} \mathrm{He},{ }^{129} \mathrm{Xe}$ and an abundance pattern characterized by relatively high concentration of $\mathrm{Ne}$. There is no known mechanism by which crustal materials can acquire these excesses. Thus, the technique intrinsically prevents misidentifying crustal materials as mantle ones.

It should be stressed that distinctive isotopic ratios of $\mathrm{Ne}, \mathrm{Ar}$ and $\mathrm{Xe}$ are observed only in well preserved mantle samples, such as MORB glasses and volcanic xenoliths. The stepwise heating experiment by Sarda et al. (1985) shows that even MORB glasses may be contaminated with crustal argon. Because of the high concentration of $\mathrm{Ar}$ and $\mathrm{Xe}$ in the crust, a small contamination from crustal materials can significantly reduce the higher mantle isotopic ratios. This is perhaps the reason that in many MORB samples, high values of ${ }^{3} \mathrm{He} /$ ${ }^{4} \mathrm{He}$ are not accompanied by high values of ${ }^{129} \mathrm{Xe} /$ ${ }^{130} \mathrm{Xe}$. The concentration of light noble gases in the crust is low, especially for ${ }^{3} \mathrm{He}$, and crustal 
contamination is therefore much less effective than in the heavier gases.

In this study, we measured the abundances of $\mathrm{Ne}, \mathrm{Ar}$ and $\mathrm{Xe}$ and the isotopic composition of $\mathrm{Ar}$ and $\mathrm{Xe}$ in 18 Kuroko ores. The result will be presented after a description of the samples and experimental procedures.

\section{SAMPles AND Procedures}

In the present study, we employ parts of the noble gas technique to investigate the genesis of the Japanese Kuroko deposits. The Kuroko deposit was selected for several reasons. Firstly, these deposits are very young, ranging from 11 to 16 my in age (Tanimura et al., 1983). This reduces interference from radiogenic products. While the Kuroko deposits are young and many of their formation features are well preserved, it should be noted that the Kuroko deposits are located in hydrothermally active area and may have undergone some geochemical modifications after formation. Secondly, the Kuroko deposits have been intensively studied and the existing data can be compared with the results of noble gas measurements. Finally, the genesis of these deposits is still con- troversial. Some authors suggest that the oreforming fluid is seawater; others think there is some magmatic contribution to the ore-forming fluid. In this study we use the noble gas technique to help identify the material source of the Kuroko ores.

\section{Samples}

Eighteen Kuroko ore samples were used in this work. They were provided by Professor H. Ohmoto of Pennsylvania State University, University Park. They are from the Fukazawa, Furotobe, Matsumine, Shakanai, Ezuri, and Kosaka mines of the Hokuroku district, Akita Prefecture, Japan. These samples are all typical specimens of Kuroko ores. They are especially valuable because some of them and other related samples have been analyzed for their $\delta \mathrm{D}, \delta^{18} \mathrm{O}$, fluid inclusion filling temperature and salinity, as well as major and minor elemental concentrations (Pisutha-Arnond and Ohmoto, 1983). Table 3 gives a brief description of the sample type, origin and location of the samples where known. The first nine samples listed there are black ores, the next five are yellow ores, and the last four are pyrite ores.

The mineralogy of these ores is simple. They

Table 3. Description of Kuroko ore samples used in this study ${ }^{a}$

\begin{tabular}{llllll}
\hline Lab. No. & \multicolumn{1}{c}{ Field No. } & Weight & Ore type & Origin (Mine) & \multicolumn{1}{c}{ Location } \\
\hline K01 & 85-FK-1A & 1.028 & Kuroko & Fukazawa & L-170 S7 28JU(WG) \\
K02 & 85-FK-1D & 0.994 & Kuroko & Fukazawa & L-170 S7 28JU(WG) \\
K03 & 85-FK-1F & 1.023 & Kuroko & Fukazawa & L-170 S7 28JU(WG) \\
K04 & 85-FK-4A & 1.074 & Kuroko & Fukazawa & L-170 S7 28JO(SG) \\
K05 & 85-FK-9C & 1.058 & Kuroko & Fukazawa & L-100 S7 \\
K06 & 85-FT-3 & 1.014 & Kuroko & Furutobe & 2 Level W13, S4 \\
K07 & 85-FT-6C & 1.012 & Kuroko & Furutobe & 0 Level E1, N2 \\
K08 & 85-MM-1B & 1.008 & Kuroko & Matsumine & L-195 S1 32 GO \\
K09 & 85-EZ-3E & 1.000 & Kuroko & Ezuri & L-125 S2 43 GO \\
K10 & JU-78-FT-12 & 0.981 & Yellow ore & Furutobe & \\
K11 & JU-79-FT-22 & 1.027 & Yellow ore & Furutobe & \\
K12 & JU-79-SK-21 & 0.987 & Yellow ore & Shakanai & \\
K13 & JU-78-SK-24 & 0.982 & Yellow ore & Shakanai & \\
K14 & JU-79-MM-004 & 1.008 & Yellow ore & Matsumine & \\
K16 & JU-79-SK-3 & 1.010 & Pyrite ore & Shakanai & \\
K17 & JU-79-SK-8 & 1.004 & Pyrite ore & Shakanai & \\
K18 & 76-11-30-7 & 1.036 & Pyrite ore & Matsumine & \\
\hline
\end{tabular}

${ }^{a}$ Field No., ore type, origin and location were provided by Professor H. Ohmoto of Pennsylvania State University, University Park, Pennsylvania. 
contain different proportions of sphalerite, galena, chalcopyrite, pyrite, and small amount of tetrahedrite. The gangue minerals in the Kuroko deposits are mainly quartz, with some barite and anhydrite. The black ores typically contain sphalerite (Tanimura et al., 1974) as their major ore mineral, followed by galena, pyrite, chalcopyrite, and a small amount of tetrahedrite in some samples. The gangue minerals in the black ores are mostly quartz, plus some barite. The yellow ores contain mainly chalcopyrite and euhedral pyrite crystals. Some of the pyrites are in perfect cubic form. The gangue minerals in the yellow ore are quartz and barite. The pyrite samples are mostly high grade ore with euhedral pyrite crystals accounting for 60-90 per cent of the samples. Considerable amounts of chalcopyrite can also be present in the pyrite ores, but the amount varies from sample to sample. These samples formed by replacement of fine-grained minerals that were previously formed by rapid precipitation at an early stage of mineralization (Barton, 1978; Eldridge et al., 1983). The major gangue mineral in the pyrite ore is quartz.

\section{Experimental procedures}

The ore samples were cleaned first with ethanol, followed by acetone. They were then crushed and ground to about 50 mesh to $2 \mathrm{~mm}$ in grain size. Samples were dried at $105^{\circ} \mathrm{C}$ for 24 hours before weighing. Each ore sample, weighing about one gram, was wrapped individually in aluminum foil. These and blanks of aluminum foil were mounted in sidearms of a sample tree, and the system pressure was then reduced to about $10^{-9}$ torr. Before gas extraction, the samples were heated under vacuum to about $180^{\circ} \mathrm{C}$ overnight to get rid of adsorbed air. For gas extraction, each sample was dropped into a previously outgassed stainless steel tube. Gas extraction was accomplished by stepwise heating, first at $600^{\circ} \mathrm{C}$ and then at $1100^{\circ} \mathrm{C}$. Suffix $\mathrm{A}$ is used to designate gas extraction at $600^{\circ} \mathrm{C}$ and suffix $\mathrm{B}$ to indicate $1100^{\circ} \mathrm{C}$. Resistance heating was used, and each gas extraction temperature was maintained for 30 minutes. The temperature was measured using a thermocouple with digital readout. The evolved gases were first cleaned on a $\mathrm{Ti}-\mathrm{Zr}$ getter furnace at about $850^{\circ} \mathrm{C}$. After this preliminary scrubbing, the first furnace was cooled to room temperature and the noble gases were transferred to a second clean-up system by adsorption on a charcoal finger maintained at liquid nitrogen temperature $\left(-196^{\circ} \mathrm{C}\right)$. The charcoal finger was then heated to about $200^{\circ} \mathrm{C}$ to release the gases for clean-up on a second $\mathrm{Ti}-\mathrm{Zr}$ getter furnace at $850^{\circ} \mathrm{C}$. After the second getter was cooled to room temperature, the charcoal finger was chilled with liquid nitrogen to adsorb the heavy noble gases. The remaining gases ( $\mathrm{He}$ and $\mathrm{Ne}$ ) were introduced into a Reynolds type mass spectrometer (Reynolds, 1956) with computercontrolled peak jumping capability for isotopic analysis. Helium was not analyzed in this study because it diffuses through the glass cleanup system and through the glass envelop of our mass spectrometer. After $\mathrm{Ne}$ analysis, this was pumped from the mass spectrometer and then Ar was introduced while Xe was retained on the charcoal finger cooled with a mixture of ethanol and solid $\mathrm{CO}_{2}$. After Ar analysis, this was pumped from the mass spectrometer, and Xe was admitted by heating the charcoal finger to $200^{\circ} \mathrm{C}$. The isotopic composition of $\mathrm{Kr}$ was not analyzed because it contains no distinguishing isotopic ratios.

Standard pipettes of noble gases were analyzed before and after the samples to obtain the sensitivity and mass discrimination of the mass spectrometer. Procedural blanks were run before each sample. Blank and instrumental mass discrimination corrections were made based on these data. Variation in the sensitivity of the mass spectrometer, as determined by five pipette analyses, was three per cent for argon; thirteen per cent for neon; and fourteen per cent for xenon.

The concentrations of each noble gas were measured by the peak height method. Data were acquired and analyzed on an HP9835B computer. Six cycles of isotopic data were collected for each gas. Within each cycle, seven readings were taken of each isotope signal, together with the time at which the readings were taken. An average of these seven readings and the time were stored in the data file for later analysis. 


\section{RESUlts AND DISCUSSION}

The results of our analyses are shown in Table 4. The three columns on the left of Table 4 show the amounts of $\mathrm{Ne}, \mathrm{Ar}$ and $\mathrm{Xe}$ released from the samples at each extraction temperature. The results shown there were calculated by the "peak height" method with the instrument sensitivity calibrated by standard pipettes. Corrections for procedural blanks were made by subtracting the signal obtained when empty aluminum foils were heated to the same temperature.

Values for the ${ }^{40} \mathrm{Ar} /{ }^{36} \mathrm{Ar}$ and the ${ }^{129-136} \mathrm{Xe} /{ }^{130} \mathrm{Xe}$ ratios are shown in the remaining six columns of Table 4. The errors listed in Table 4 are one standard deviation $(\sigma)$. They are cumulative errors that include statistical fluctuations in the signal of the sample and blank, but do not include the uncertainty in the absolute sensitivity of the mass spectrometer. No anomalous ratios were observed for neon nor for the ${ }^{38} \mathrm{Ar} /{ }^{36} \mathrm{Ar}$ isotopic ratios. The ${ }^{128} \mathrm{Xe} /{ }^{130} \mathrm{Xe}$ ratio is not reported because of background interference in the mass spectrometer. The signals of ${ }^{124} \mathrm{Xe}$ and ${ }^{126} \mathrm{Xe}$ were too low to measure without using long signal collection time that would reduce the quality of the more interesting xenon isotopes.

\section{Noble gas isotopic ratios}

It can be seen from Table 4 that several of the Kuroko ores contain a small excess of ${ }^{40} \mathrm{Ar}$. The absence of large enrichments of radiogenic ${ }^{40} \mathrm{Ar}$ in these samples is not unexpected. From data reported earlier for K-Ar dating of 19 minerals and rocks from the Kuroko area (Metal Mining Agency of Japan, 1981, 1982, 1984), we calculated that the observed values of the ${ }^{40} \mathrm{Ar} /{ }^{36} \mathrm{Ar}$ ratio in these $\mathrm{K}$-rich samples ranged from 330 to 2070 . Relative to atmospheric argon, the enrichment of ${ }^{40} \mathrm{Ar}$ in our samples is $\leq 10 \%$ of the total ${ }^{40} \mathrm{Ar}$ released from any of the Kuroko ores, except for the gas released at $1100^{\circ} \mathrm{C}$ from $\mathrm{K} 01, \mathrm{~K} 08, \mathrm{~K} 15$ and $\mathrm{K} 16$ and the gas released at $600^{\circ} \mathrm{C}$ from $\mathrm{K} 15$ and $\mathrm{K} 16$. Of these six gas fractions with significant enrichments of ${ }^{40} \mathrm{Ar}$, four came from pyrite ores and two from black ores.
The upper mantle was exhaustively degassed in an early period of the Earth's history which produced its crust and atmosphere (Manuel and Sabu, 1981; Allègre et al., 1987). Accumulation of radiogenic argon increased the inventory of ${ }^{40} \mathrm{Ar}$ in the upper mantle. Therefore, the upper mantle usually has high values of ${ }^{40} \mathrm{Ar} /{ }^{36} \mathrm{Ar}$. These values can be seen in well preserved mantle samples. Sarda et al. (1985) observed values of the ${ }^{40} \mathrm{Ar} /$ ${ }^{36} \mathrm{Ar}$ ratio as high as 25,250 in MORB glass by stepwise heating. The average value of this ratio for the 33 glassy MORB samples analyzed by Sarda et al. (1985) is 8,660 . However, crustal contamination can decrease the ${ }^{40} \mathrm{Ar} /{ }^{36} \mathrm{Ar}$ ratio so that it approaches sedimentary or even atmospheric values. Allègre et al. (1987) estimated a mean value of ${ }^{40} \mathrm{Ar} /{ }^{36} \mathrm{Ar}=16,700$ for MORB. We will show later that as little as $2 \%$ of seawater contamination in MORB glass would reduce the value of its ${ }^{40} \mathrm{Ar} /{ }^{36} \mathrm{Ar}$ ratio from 16,700 to 350 . We will also show that $25 \%$ of seawater contamination in the hydrothermal fluid that equilibrated with MORB would reduce the ${ }^{40} \mathrm{Ar} /{ }^{36} \mathrm{Ar}$ ratio from 16,700 to 700 .

The slight enrichment that we observed in values of the ${ }^{40} \mathrm{Ar} /{ }^{36} \mathrm{Ar}$ ratio for Kuroko ore samples might indicate a component of argon from a deep source that was diluted with another component of atmospheric argon. Alternatively, in situ decay of ${ }^{40} \mathrm{~K}$ would naturally increase values of the ${ }^{40} \mathrm{Ar} /{ }^{36} \mathrm{Ar}$ ratio. We calculated that a $\mathrm{K}$ content of 1-30 ppm would be sufficient to generate all of the excess ${ }^{40} \mathrm{Ar}$ observed in these ores over a time period of 15 my (Tanimura et al., 1983).

Most of the xenon isotopic ratios of the Kuroko ores are atmospheric within $2 \sigma$ of error, except for some small enrichment of ${ }^{134} \mathrm{Xe}$ and ${ }^{136} \mathrm{Xe}$ caused by the fission of uranium. Xenon in the depleted upper mantle is characterized by ${ }^{129} \mathrm{Xe} /{ }^{130} \mathrm{Xe}=$ 7.36 (Allègre et al., 1987), which is higher than the ${ }^{129} \mathrm{Xe} /{ }^{130} \mathrm{Xe}$ ratio in air by about $13.6 \%$. This ${ }^{129} \mathrm{Xe}$ excess is much smaller than that of ${ }^{40} \mathrm{Ar}$. The ${ }^{129} \mathrm{Xe}$ excess is also much easier to mask by seawater dilution. Therefore, excess ${ }^{129} \mathrm{Xe}$ is not expected in case of substantial seawater dilution.

As can be seen from Table 4, there are some 


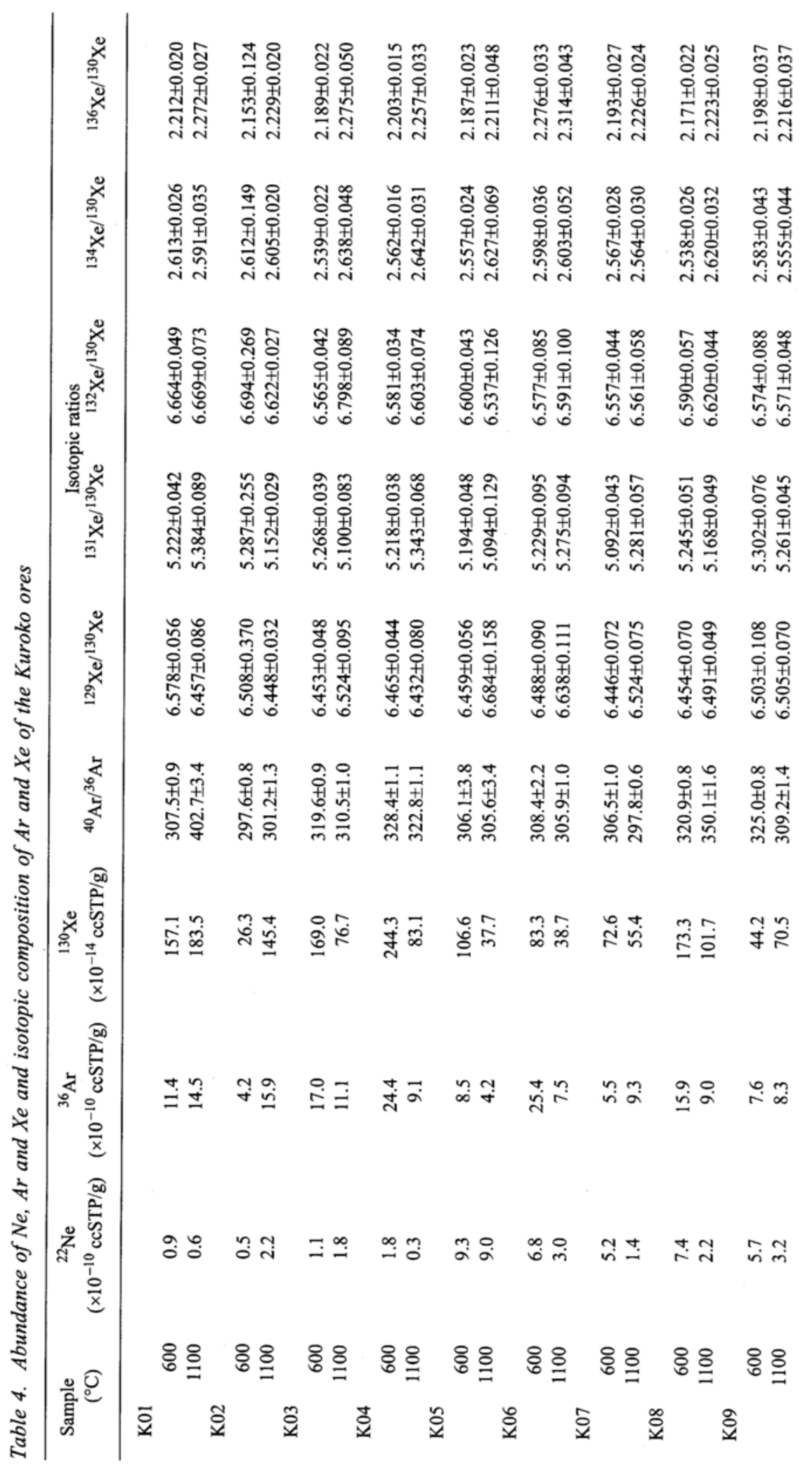




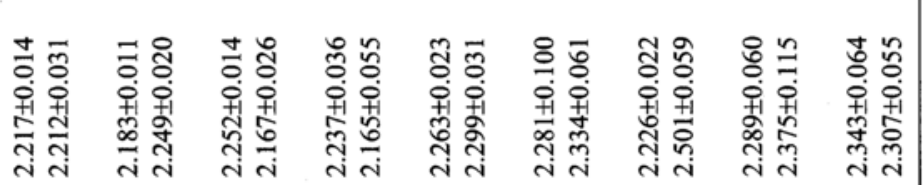

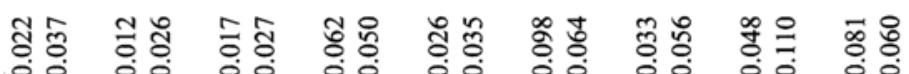

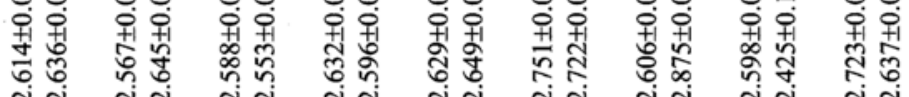
i

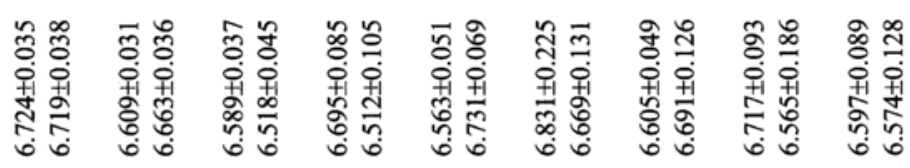

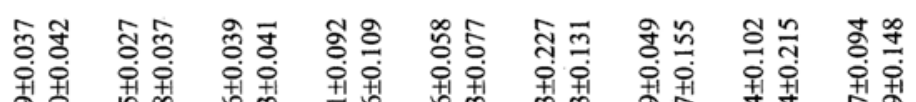

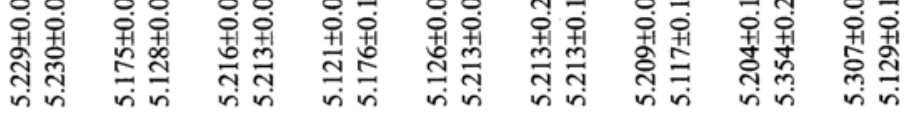

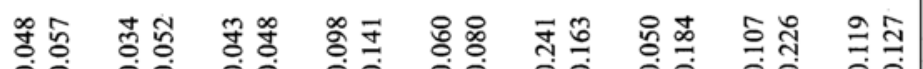

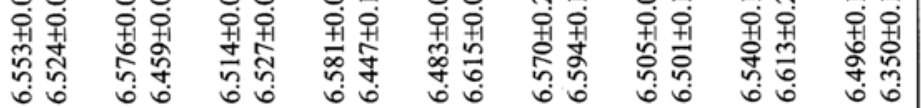

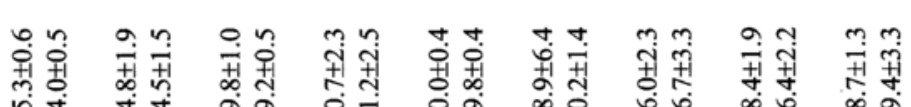

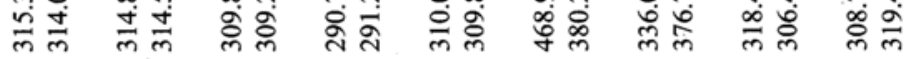

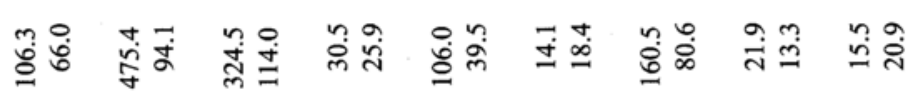

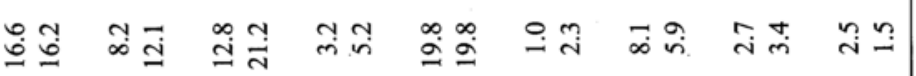

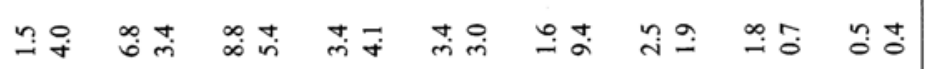

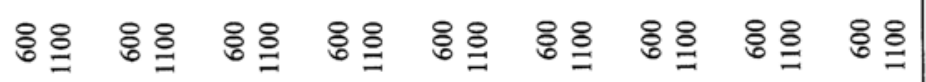

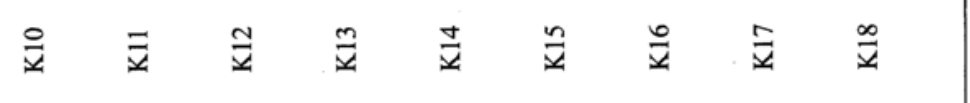




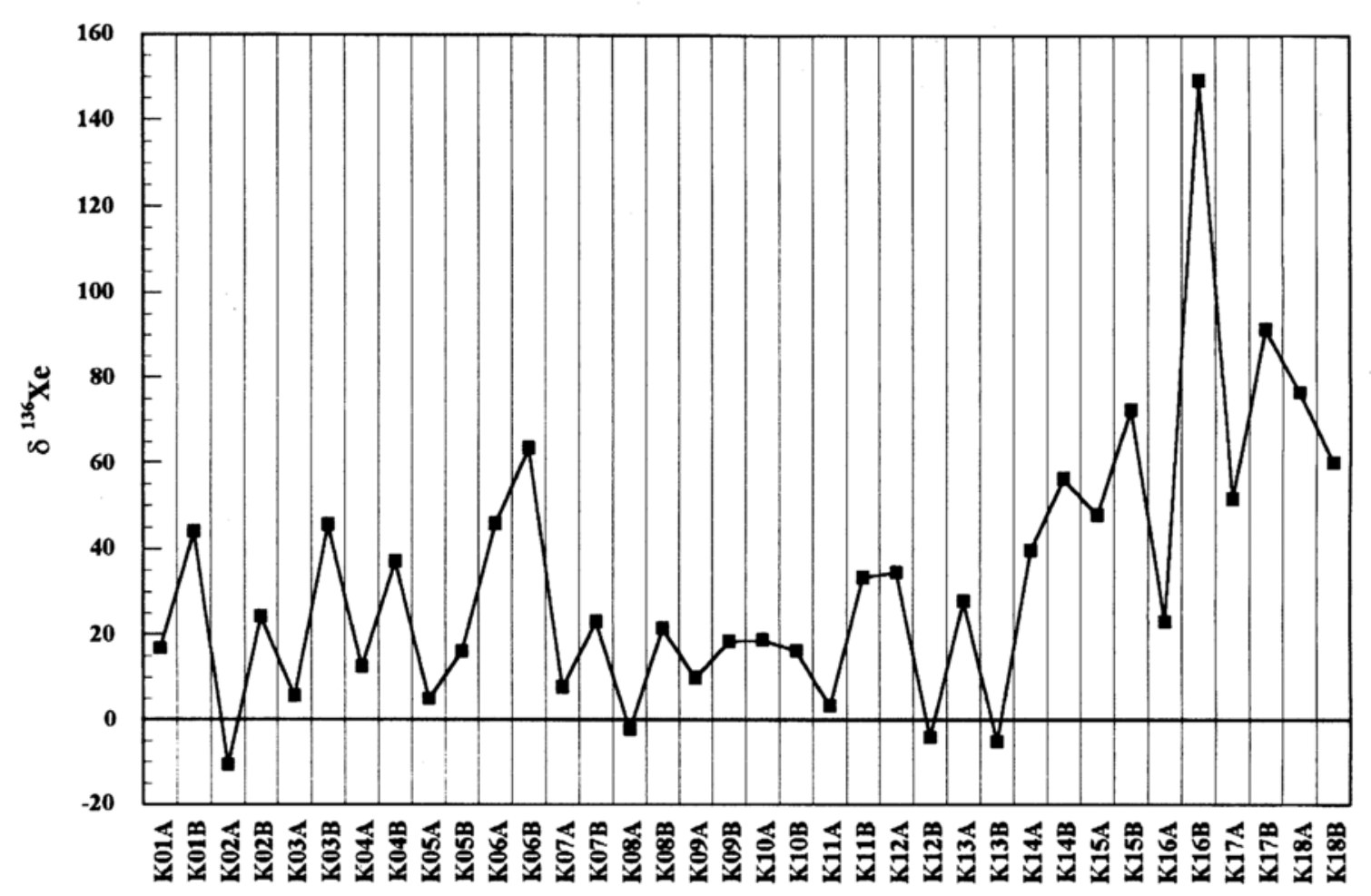

Fig. 2. Fissiogenic xenon in the Kuroko ores. The $\delta^{136} X e$ values are generally higher than that of air. The highest enrichments of ${ }^{136} \mathrm{Xe}$ occur in the pyrite ores which are formed latest in the formation sequence of the different types of ores. This suggests a decreasing role of seawater in the formation of pyrite ores.

enrichments of ${ }^{134} \mathrm{Xe}$ and ${ }^{136} \mathrm{Xe}$, especially for the pyrite ores. The highest excess is at ${ }^{136} \mathrm{Xe}$, owing to its low natural abundance and its high yield in the spontaneous fission of ${ }^{238} \mathrm{U}$. For example, the ${ }^{136} \mathrm{Xe} /{ }^{130} \mathrm{Xe}$ ratios of $\mathrm{K} 15 \mathrm{~B}, \mathrm{~K} 16 \mathrm{~B}, \mathrm{~K} 17 \mathrm{~B}$, and $\mathrm{K} 18 \mathrm{~A}$ are substantially higher than that of air. The fissiogenic ${ }^{136} \mathrm{Xe}$ excess is plotted in Fig. 2. The $\delta^{136} \mathrm{Xe}$ value in the ordinate of Fig. 2 is defined as follows:

$$
\delta^{136} \mathrm{Xe}(\%)=\left[\frac{\left({ }^{136} \mathrm{Xe} /{ }^{130} \mathrm{Xe}\right)_{\text {sample }}}{\left({ }^{136} \mathrm{Xe} /{ }^{130} \mathrm{Xe}\right)_{\text {air }}}-1\right] \times 1000 .
$$

As can be seen from Fig. 2, many of the samples display positive anomalies of ${ }^{136} \mathrm{Xe}$, as expected if fissiogenic xenon is present. With the pyrite samples, the $\delta^{136} \mathrm{Xe}$ value can be as high as 149 per mil (K16B). The general trend is that the black ore and the yellow ore have smaller fission contribution to their xenon than do the pyrite ores. This trend might be explained by the ore formation sequence deduced from mineral texture studies by Barton (1978) and Eldridge et al. (1983). Mineral texture studies indicate that the black ores formed first on the sea floor during the initial precipitation and then recrystallized in the lower part of the ore pile as it accumulated. Next, Cu-rich hydrothermal fluids came up and replaced the previously formed black ores, forming yellow ores. Later, hot fluids were introduced. These replaced the chalcopyrite and formed pyrite ores. According to the above sequence, the seawater influence decreases from black ore to yellow ore to pyrite ore because the later formed ores were more insulated from seawater than the black ores. Since contamination with seawater can erase the anomalies from fissiogenic xenon, the fissiogenic xenon had a better chance to be preserved in the later formed ore samples. 
The presence of fissiogenic xenon in the pyrite ores may therefore indicate that the hydrothermal fluids that formed the pyrite ores were of magmatic origin, since seawater contains no fission xenon. Circulation of seawater through igneous rocks could not increase the ${ }^{136} \mathrm{Xe} /{ }^{130} \mathrm{Xe}$ ratio in seawater because it has a much higher concentration of Xe than igneous rocks.

The in situ production of fissiogenic Xe offers another possible interpretation of the higher values of the ${ }^{136} \mathrm{Xe} /{ }^{130} \mathrm{Xe}$ ratio in the pyrite ore. The amounts of $\mathrm{Xe}$ trapped in the other ore samples are higher by a factor of $3-4$, and the ${ }^{136} \mathrm{Xe}$ anomaly would therefore be lower by a factor of 3-4 if they contain the same amount of fissiogenic
$\mathrm{Xe}$ as the pyrite ore. However, we estimated that about $5 \mathrm{ppm}$ of $\mathrm{U}$ would be required to produce the amount of fissiogenic ${ }^{136} \mathrm{Xe}$ observed in our samples of Kuroko ores over a time period of 15 my.

In summary, the ${ }^{40} \mathrm{Ar} /{ }^{36} \mathrm{Ar}$ ratios of the 18 Kuroko ores are only slightly higher than the seawater value. The isotopic ratios of xenon and neon extracted from these samples are atmospheric except for some fissiogenic xenon anomalies in the pyrite samples. The absence of large excesses of ${ }^{129} \mathrm{Xe}$ and ${ }^{40} \mathrm{Ar}$ must be explained by contamination if these Kuroko samples were originally mantle derived. On the other hand, if the Kuroko samples originally trapped only atmospheric gases,

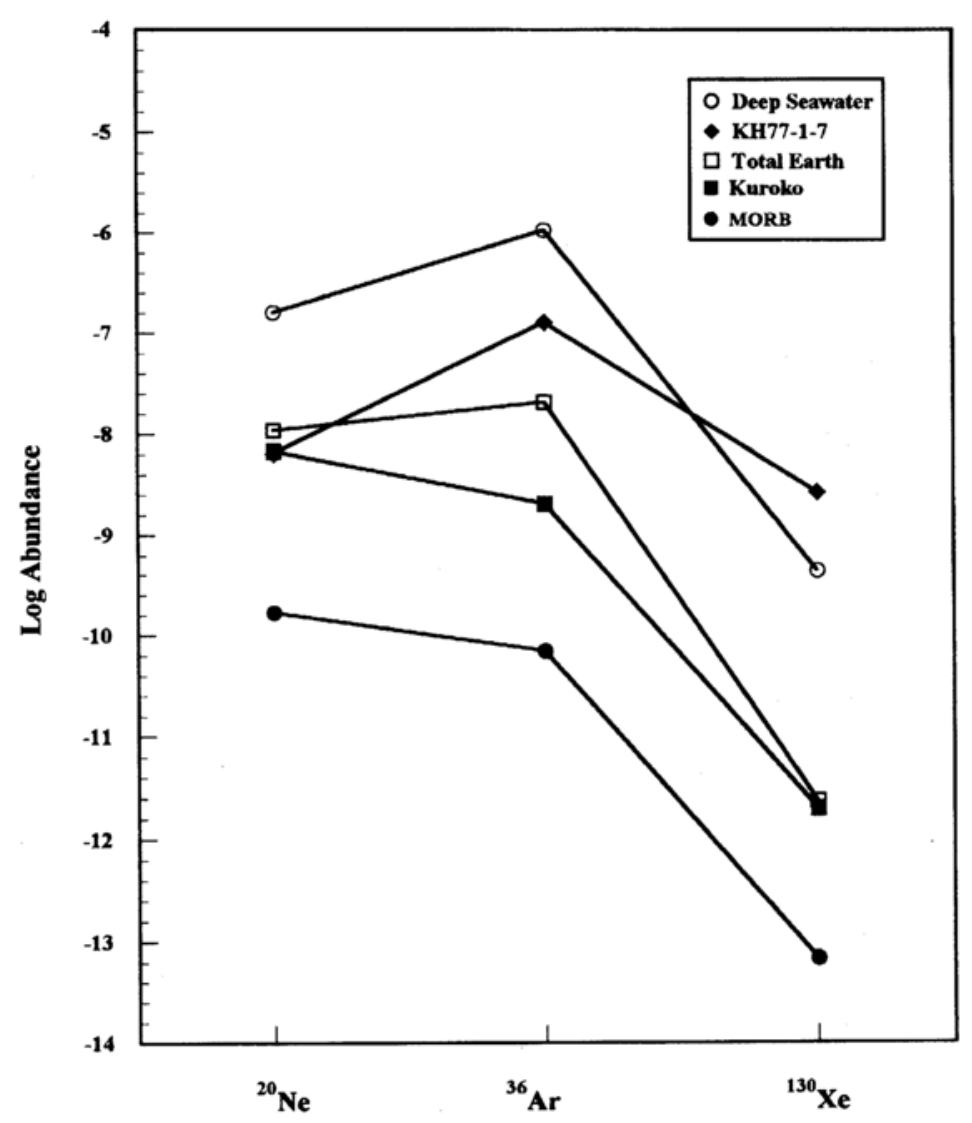

Fig. 3. Comparison of noble gas abundance patterns of MORB, Kuroko, seawater and other related samples. Note that the Kuroko samples are intermediate between MORB and deep seawater. The absolute abundance and the abundance pattern of noble gases in the Kuroko ores are closer to those of MORB. MORB and deep seawater data are from Allègre et al. (1987). KH77-1-7 and total Earth data are from Ozima and Podosek (1983). 
then this would be consistent with the conclusion by Ohmoto and Takahashi (1983) that "only a small portion, if any, of the water initially present in the magma could have participated in the ore forming fluids."

\section{Neon, argon and xenon abundances}

The concentrations and elemental ratios of noble gases can also be used to help identify the source of the Kuroko ore deposits. For example, the concentration of $\mathrm{Ne}$ in Kuroko ores (Table 4) is generally higher than those reported in Fig Tree shale and sea floor sediments (Table 1), but the concentrations of $\mathrm{Ar}$ and $\mathrm{Xe}$ in the Kuroko ores are one to three orders-of-magnitude below those in Fig Tree shale and sea floor sediments. The concentration of $\mathrm{Xe}$ in many Kuroko ores is less than the lowest value that Ozima and Podosek (1983) show in their Fig. 8.7 for Xe in a large suite of sedimentary rocks.

The $\mathrm{Ne}, \mathrm{Ar}$ and $\mathrm{Xe}$ concentrations in Kuroko ores (Table 4) are typical of the values that Ozima and Podosek show in their Figs. 9.3, 9.4 and 9.6, respectively, for the $\mathrm{Ne}, \mathrm{Ar}$ and $\mathrm{Xe}$ in igneous rocks. MORB is one type of the igneous rocks with low concentrations of noble gases. As we shall show below, the abundance pattern of noble gases in Kuroko ores parallels that in MORB.

Figure 3 compares the average noble gas concentration of the Kuroko ores with those in MORB (Allègre et al., 1987), in sea floor sediment, KH771-7 (Podosek et al., 1980), in deep seawater (Allègre et al., 1987) and in the total Earth, calculated by dividing noble gases in air by the total mass of the Earth (Ozima and Podosek, 1983). It can be seen from Fig. 3 that the concentrations of noble gases in the Kuroko ores are uniformly about 1.5 orders-of-magnitude higher than those in MORB. The abundance pattern of noble gases in Kuroko ores is similar to that in MORB (Allègre et al., 1987) and other igneous rocks (Ozima and Podosek, 1983).

Since debates on the genesis of Kuroko ores center on the roles of seawater and juvenile hydrothermal fluid from magma, it is of special interest that the noble gas concentrations of seawater are 3-4 orders-of-magnitude higher than those of MORB, which is generally considered to be from the upper mantle. Note that noble gases in the deep-sea sediment, $\mathrm{KH} 77-1-7$, which likely formed in equilibration with deep seawater, are progressively enriched in heavier noble gases. This pattern is a general property of the sedimentation process (Ozima and Podosek, 1983; Podosek et al., 1980). The noble gas abundance pattern in the Kuroko ores is unlike that produced by sedimentation.

Figure 4 shows the abundance pattern of noble gases in the Kuroko ores, as shown in Fig. 1 for other terrestrial noble gas reservoirs (Ozima and Alexander, 1976). Figure 4d shows the range of values of $F^{m}$ for all the Kuroko ores analyzed in this study. The heavy line there represents the average noble gas concentration for 18 ores analyzed. The other three drawings in Fig. 4 show the range of values of $F^{m}$ for the three different types of Kuroko ores analyzed in this study. From a comparison of the noble gas abundance patterns shown in Fig. 4 with those shown earlier in Fig. 1, we concluded that:

i) None of the Kuroko ores analyzed in this study contain noble gases with the Type 1a or Type $1 \mathrm{~b}$ abundance patterns. Ozima and Alexander (1976) noted that the Type 1a and 1b abundance patterns were produced by absorption of atmospheric noble gases into water.

ii) None of the Kuroko ores analyzed in this study contain noble gases with the Type 3 abundance pattern (Fig. 1). Values of the Xe/Ar ratio in the Kuroko ores are much lower than those shown for the Type 3 abundance pattern.

iii) The abundance patterns of the noble gases in all 18 Kuroko ore samples are most like the Type 2 pattern shown in Fig. 1. Ozima and Alexander (1976) interpreted the Type 2 pattern to be primordial noble gases from the Earth's mantle.

The abundances of noble gases in Kuroko ores are like those that Ozima and Podosek (1983) report in a large suite of igneous rocks, including submarine and subareal volcanics, xenoliths, diamonds and plutonic rocks. 

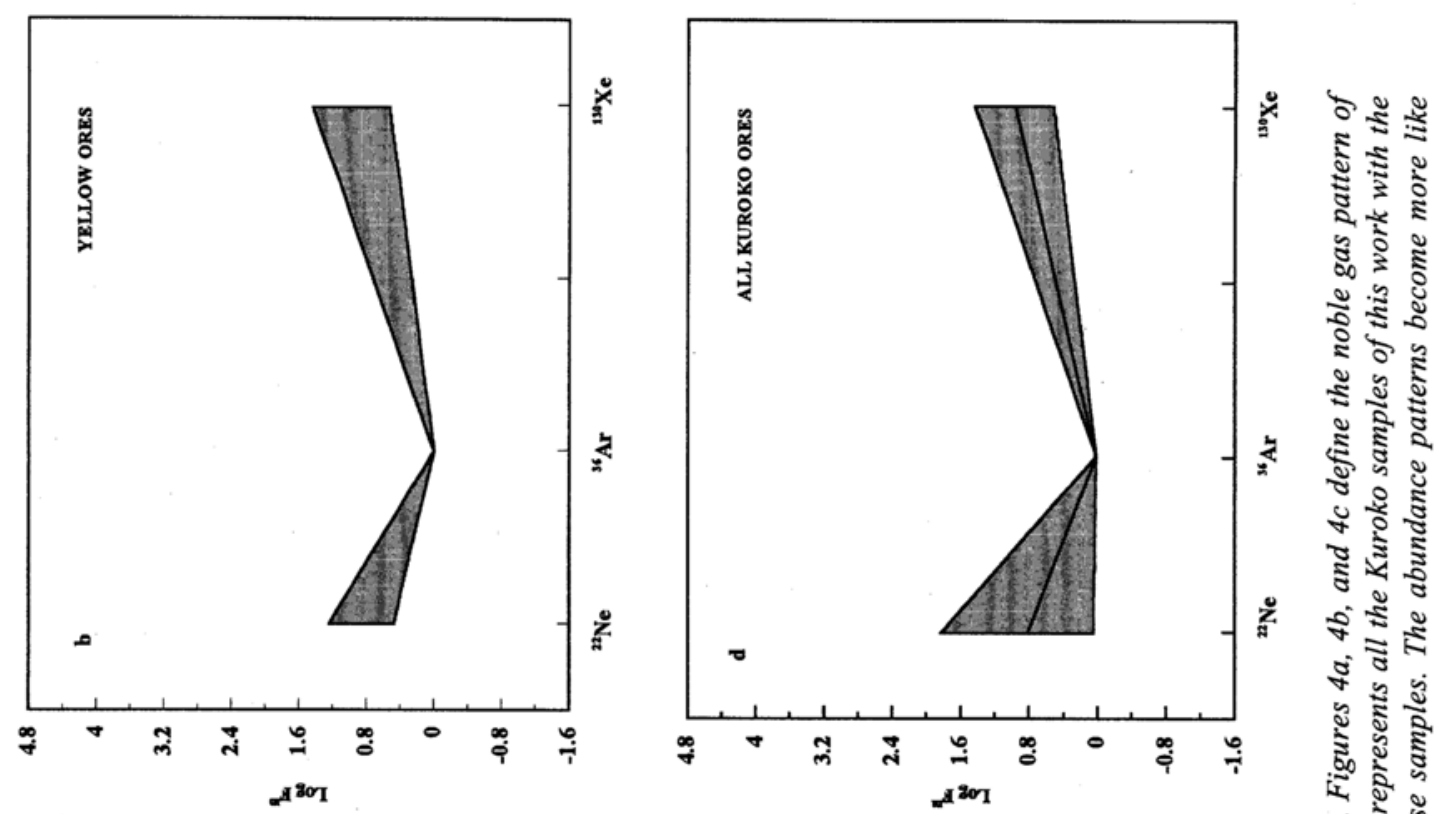

造 क
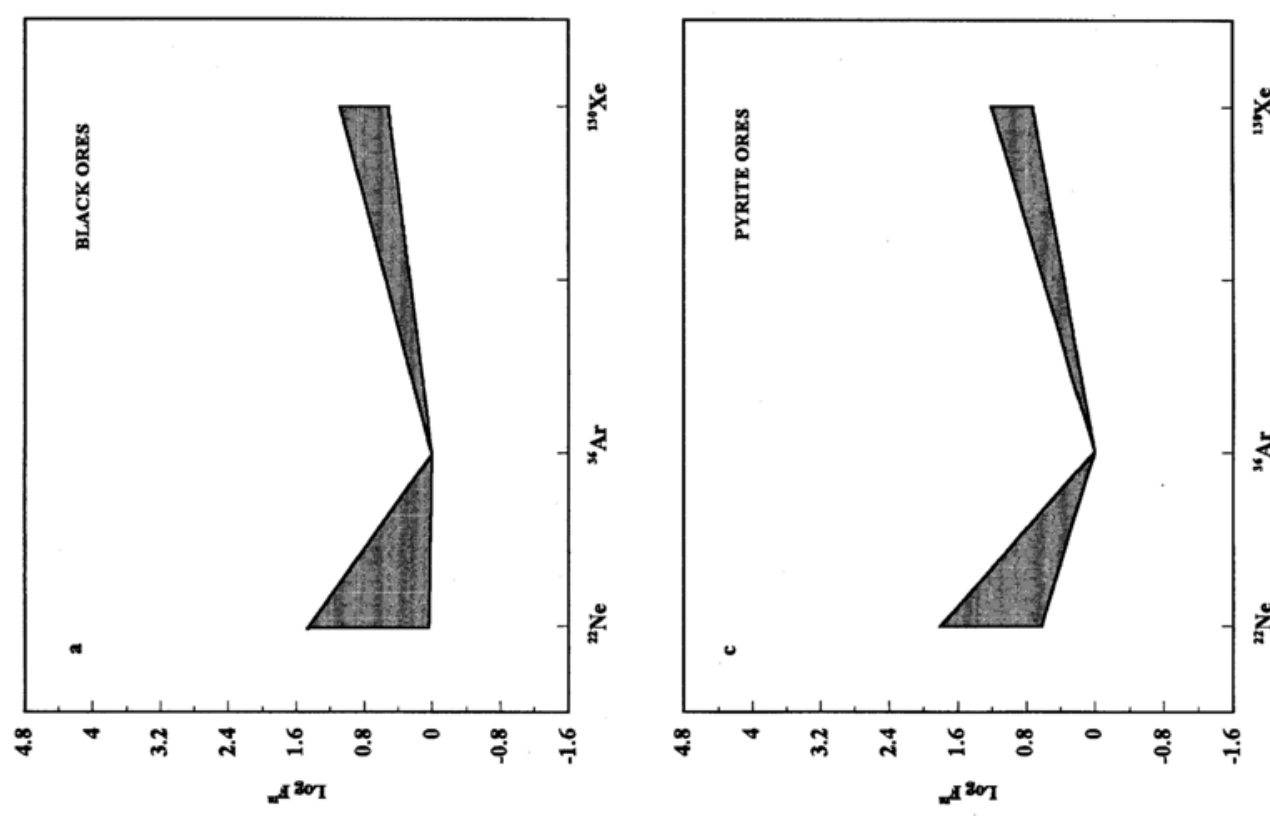

จ

竎

ㅇํㅇำ

茫

จ. ปั.

दूर

竎

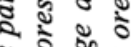

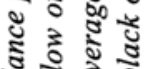

จี डे

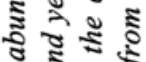

वे के

$\infty$ 每

के के

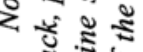

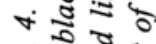

造范 
It can be seen from Fig. 4 that the noble gas abundance pattern in each of the three types of Kuroko ores resembles the Type 2 pattern. However, there are some interesting variations, especially with respect to $\mathrm{Ne}$. The relative abundance of $\mathrm{Ne}$ is the main factor that distinguishes the noble gas abundance pattern for the mantle from that observed in seawater and seawater-related products. Some of the black ores have low concentrations of $\mathrm{Ne}$ relative to ${ }^{36} \mathrm{Ar}$, i.e., values of $F^{22}$ defined by Eq. (1) are low for these ores (Fig. $4 a)$. The range of values of $F^{22}$ for the yellow ores (Fig. 4b) is narrower than the black ores. The highest values of $F^{22}$ are observed for the pyrite ores (Fig. 4c). In a word, there exists a trend from black ore to yellow to pyrite ore such that the noble gas abundance patterns become more like that of a magmatic source. This trend is in good agreement with the formation sequence that Barton (1978) and Eldridge et al. (1983) proposed for these ores: The black ores formed first on the sea floor. The yellow ores then formed through the replacement of the black ores by hydrothermal fluids. The pyrite ores formed last by replacement of the yellow ores. In this formation sequence, the influence of seawater decreases from black ore to yellow ore to pyrite ore because the later formed ores are more insulated from seawater by the earlier formed ores. This is the trend that we noted in the values of $F^{22}$ in Fig. 4: The noble gas abundance patterns become more like that of the magmatic source as the role of seawater decreases.

\section{A binary mixing model for the Kuroko deposits}

The concentrations and abundance patterns of noble gases in Kuroko ores indicate that the oreforming fluid of these deposits is mainly of magmatic origin. However, geological evidence suggests that the Kuroko deposits formed in sea floor depressions through chemical precipitation. Some participation of seawater in the formation of the Kuroko deposits seems inevitable. Debate about the genesis of Kuroko deposits has focused on the roles of seawater and magmatic source fluid in the formation of the these deposits. Therefore, it is instructive to evaluate the relative contributions of seawater and magmatic fluid to the Kuroko oreforming fluid. In this section, we will evaluate these contributions by calculating the distribution coefficients of noble gases between solid and fluid, assuming the fluid is a binary mixture of magmatic fluid and seawater. The calculations are as follows:

i) From the noble gas concentrations in seawater and in two crystalline diabase samples that have equilibrated with seawater (Dymond and Hogan, 1973), we first calculate the distribution coefficients of $\mathrm{Ne}, \mathrm{Ar}$, and Xe between this fluid (seawater) and solid rocks:

$$
D=\frac{C_{\mathrm{S}}}{C_{\mathrm{F}}} .
$$

Here $C_{\mathrm{S}}$ and $C_{\mathrm{F}}$ are noble gas concentrations in the solid and fluid, respectively.

ii) Assuming the Kuroko ores and the submarine glass samples also equilibrated with their corresponding fluids, as defined by Eq. (3), the concentration of noble gases in the source fluids, $C_{\mathrm{F}}$, of Kuroko and submarine glasses can be computed from those in the solids, $C_{\mathrm{S}}$ :

$$
C_{\mathrm{F}}=\frac{C_{\mathrm{S}}}{D}
$$

iii) From the noble gas concentrations obtained above for the Kuroko source fluid and the magmatic source fluid, we then calculate the contribution of seawater and the magmatic source fluid to the ore-forming fluid of Kuroko, using a binary mixing model:

$$
\left\{\begin{array}{l}
x C_{\mathrm{MF}}+y C_{\mathrm{SW}}=C_{\mathrm{KF}}, \\
x+y=1
\end{array}\right.
$$

where $x$ and $y$ are the fractions of Kuroko ore fluid derived from magmatic and seawater sources, respectively. $C_{\mathrm{MF}}, C_{\mathrm{SW}}$ and $C_{\mathrm{KF}}$ represent the noble gas concentrations in the magmatic source fluid, in seawater and in the Kuroko source fluid, respectively. 
The binary model requires that $0 \leq x, y \leq 1$. This model also requires a closed system, i.e., the contributions from magmatic source and seawater are completely used in the formation of the Kuroko deposits. Ne is not included in Table 6 because it does not meet the closed system requirement of this binary mixing model.

Dymond and Hogan $(1973,1978)$ studied the gas retentivity of MORB glasses and the associated holocrystalline rocks. Their results indicate that only the quenched glassy rim $(0-1 \mathrm{~cm})$ of the basalt pillow retains mantle Ar quantitatively, as indicated by a high ${ }^{40} \mathrm{Ar} /{ }^{36} \mathrm{Ar}$ ratio. Further into the pillow to about $10 \mathrm{~cm}$, the concentration of the light gases tends to decrease and those of the heavier gases tend to increase. In other words, the abundance pattern of noble gases in these MORB samples becomes more like the Type 1 pattern of seawater. The value of the ${ }^{40} \mathrm{Ar} /{ }^{36} \mathrm{Ar}$ ratio decreased with distance from the glassy rim, suggesting isotopic exchange between the seawater and the cooling magmatic intrusive rocks. Two holocrystalline samples taken from the same location show even more severe depletion of light gases and enrichment in heavier ones. The ${ }^{40} \mathrm{Ar} /{ }^{36} \mathrm{Ar}$ ratio in the holocrystalline samples is indistinguishable from that in seawater, indicating that they have reached equilibrium with seawater. By using Eq. (3), we calculated the distribution coefficients of $\mathrm{Ne}, \mathrm{Ar}$ and $\mathrm{Xe}$ between these diabase samples and deep seawater (Allègre et al., 1987) to be $5.4 \times 10^{-3}, 7.0 \times 10^{-3}$ and $1.6 \times 10^{-2}$, respectively. The values obtained for these distribution coefficients are in good agreement with those of other "incompatible" trace elements in typical magmatic differentiation (Ozima and Podosek, 1983).

If these same distribution coefficients are used in Eq. (4) to calculate the concentrations of noble gases in the hypothetical source fluids for the first five submarine glasses reported by Dymond and Hogan (1973), we obtain the results shown in Table 5. The average values for the source fluids of these five submarine glasses are $7.2 \times 10^{-7}$ ccSTP ${ }^{22} \mathrm{Ne} / \mathrm{g}, 8.5 \times 10^{-8} \mathrm{ccSTP}{ }^{36} \mathrm{Ar} / \mathrm{g}$ and $1.6 \times$ $10^{-11} \mathrm{ccSTP}{ }^{130} \mathrm{Xe} / \mathrm{g}$. These are shown in Table 5, together with those calculated in a similar manner of the source fluid of MORB samples (Allègre et $a l ., 1987)$ and the Kuroko ores analyzed in this study. For comparison, we have also shown the concentrations of noble gases in deep seawater (Allègre et al., 1987).

It can be seen from Table 5 that the concentrations of $\mathrm{Ar}$ and $\mathrm{Xe}$ for the hypothetical Kuroko

Table 5. Noble gas concentration of seawater and those calculated for the source fluids for MORB, glassy basalts and Kuroko ores

\begin{tabular}{lccc}
\hline Source fluid & $\begin{array}{c}{ }^{22} \mathrm{Ne} \\
\left(\times 10^{-10} \mathrm{ccSTP} / \mathrm{g}\right)\end{array}$ & $\begin{array}{c}{ }^{36} \mathrm{Ar} \\
\left(\times 10^{-10} \mathrm{ccSTP} / \mathrm{g}\right)\end{array}$ & $\begin{array}{c}{ }^{130} \mathrm{Xe} \\
\left(\times 10^{-14} \mathrm{ccSTP} / \mathrm{g}\right)\end{array}$ \\
\hline Pillow basalt $^{a}$ & & & \\
Y7105 & 5,075 & 291 & 1,926 \\
Amph 3E & 11,128 & 1,217 & 1,095 \\
TW 4-10 & 11,661 & 1,051 & 1,424 \\
TW 9-35 & 5,179 & 732 & 1,282 \\
V25-1-T2 & 3,258 & 974 & 2,054 \\
Average & 7,260 & 853 & 1,556 \\
& & & 432 \\
MORB $^{b}$ & 32 & 106 & 12,500 \\
Kuroko $^{c}$ & 1,289 & 2,900 & 45,100 \\
Seawater $^{d}$ & 178 & 12,700 & \\
\hline
\end{tabular}

${ }^{a}$ Calculated from noble gas concentrations of submarine glasses of Dymond and Hogan (1973).

${ }^{b}$ Calculated from noble gas concentrations in MORB Allègre et al. (1987).

${ }^{c}$ Calculated from average noble gas concentrations in Kuroko ores.

${ }^{d}$ Allègre et al. (1987). 
source fluid are intermediate between those of deep seawater and the source fluids for the glassy rims of pillow basalts and MORB. These concentrations can be used with Eq. (5) to estimate the relative contribution of the magmatic source and seawater to the inventory of $\mathrm{Ar}$ and $\mathrm{Xe}$ in the Kuroko ores. Since the debate about the genesis of the Kuroko deposits is focused on the roles of seawater and magmatic hydrothermal fluids as possible ore source fluids, we used the concentrations of $\mathrm{Ar}$ and $\mathrm{Xe}$ to calculate the contributions of deep seawater and the magmatic source fluid to the Kuroko ore fluid. The results of these calculations are shown in Table 6. The submarine glasses are from Dymond and Hogan (1973). The igneous rock data shown there are from Table 9.1 of Ozima and Podosek (1983), plus the MORB data from Allègre et al. (1987).

For the top five submarine glasses (Dymond and Hogan, 1973) listed in Table 6 and for all of the other igneous rocks tabulated there (Ozima and Podosek, 1983; Allègre et al., 1987), our calculations suggest that about $75-80 \%$ of the Kuroko ore fluid is of magmatic origin. Concentrations of heavier gases are less affected by processes that occurred subsequent to solidification. For this reason, we prefer the results based on Xe: $75 \%$ of
Kuroko's ore-forming fluid came from a magmatic source and the remaining $25 \%$ came from seawater.

The atmospheric-like ${ }^{40} \mathrm{Ar} /{ }^{36} \mathrm{Ar}$ and ${ }^{129} \mathrm{Xe} /{ }^{130} \mathrm{Xe}$ ratios in Kuroko ores suggest that the magmatic source fluid of the Kuroko deposits did not contain the isotopic signature of the upper mantle. This can be explained by contamination with crustal materials, e.g., by subduction of sea floor sediments into the upper mantle or by the assimilation of crustal material as the magma ascended. The data tabulated in Table 1 suggest that sea floor sediments and/or seawater are two plausible carriers of crustal rare gases. The noble gas concentrations in these are very high, especially for the heavy noble gases. For the Kuroko deposits, the addition of seawater was inevitable since these deposits were formed on the sea floor. In the rest of this section, we will try to evaluate the effect of seawater contamination on the ${ }^{40} \mathrm{Ar} /{ }^{36} \mathrm{Ar}$ and ${ }^{129} \mathrm{Xe} /{ }^{130} \mathrm{Xe}$ ratios of mantle-derived samples.

Seawater dilution of magmatic materials can be approximated in two ways. One is the dilution of magmatic hydrothermal fluid by seawater. The other is the direct dilution of solidified magmatic rocks by seawater. The ${ }^{36} \mathrm{Ar}$ concentration and ${ }^{40} \mathrm{Ar} /{ }^{36} \mathrm{Ar}$ ratio are $7.4 \times 10^{-11} \mathrm{ccSTP} / \mathrm{g}$ and 16,700

Table 6. Fractional contributions of magmatic source fluid and seawater to the Kuroko ore fluid

\begin{tabular}{|c|c|c|c|c|c|c|}
\hline \multirow[t]{2}{*}{ Sample } & \multirow{2}{*}{$\begin{array}{c}{ }^{36} \mathrm{Ar} \\
\left(\times 10^{-10} \mathrm{ccSTP} / \mathrm{g}\right)\end{array}$} & \multirow{2}{*}{$\begin{array}{c}{ }^{130} \mathrm{Xe} \\
\left(\times 10^{-14} \mathrm{ccSTP} / \mathrm{g}\right)\end{array}$} & \multicolumn{2}{|c|}{ Seawater fractions } & \multicolumn{2}{|c|}{ Magmatic fractions } \\
\hline & & & $\mathrm{Ar}$ & $\mathrm{Xe}$ & $\mathrm{Ar}$ & $\mathrm{Xe}$ \\
\hline \multicolumn{7}{|l|}{ Submarine glasses ${ }^{a}$} \\
\hline Y7105 & 2.04 & 30.77 & 0.21 & 0.25 & 0.79 & 0.75 \\
\hline Amph 3E & 8.53 & 17.50 & 0.15 & 0.26 & 0.85 & 0.74 \\
\hline TW 4-10 & 7.36 & 22.75 & 0.16 & 0.25 & 0.84 & 0.75 \\
\hline TW 9-35 & 5.13 & 20.47 & 0.18 & 0.26 & 0.82 & 0.74 \\
\hline $\mathrm{V} 25-1-\mathrm{T} 2$ & 6.82 & 32.80 & 0.17 & 0.24 & 0.83 & 0.76 \\
\hline \multicolumn{7}{|l|}{ Other igneous rocks } \\
\hline Hawaiian Dunite $^{b}$ & 4.00 & 13.00 & 0.20 & 0.26 & 0.80 & 0.74 \\
\hline Hawaiian Dunite ${ }^{b}$ & 3.00 & 24.00 & 0.20 & 0.25 & 0.80 & 0.75 \\
\hline Spinel Iherzolite $b$ & 2.00 & 23.00 & 0.21 & 0.25 & 0.79 & 0.75 \\
\hline $\operatorname{EPR}(735-1)^{b}$ & 2.00 & 7.00 & 0.21 & 0.27 & 0.79 & 0.73 \\
\hline MORB $^{c}$ & 0.74 & 6.90 & 0.23 & 0.27 & 0.77 & 0.73 \\
\hline
\end{tabular}

${ }^{a}$ Dymond and Hogan (1973).

${ }^{b}$ Ozima and Podosek (1983).

cAllègre et al. (1987). 
Table 7. The effect of seawater dilutions on ${ }^{40} \mathrm{Ar}{ }^{36} \mathrm{Ar}$ ratio of MORB and submarine glasses

\begin{tabular}{|c|c|c|c|c|c|c|c|c|}
\hline \multirow{3}{*}{$\begin{array}{l}\text { Diluted } \\
{ }^{40} \mathrm{Ar} /{ }^{36} \mathrm{Ar}\end{array}$} & \multicolumn{4}{|c|}{ Direct dilution } & \multicolumn{4}{|c|}{ Source fluid dilution } \\
\hline & \multicolumn{2}{|c|}{$\mathrm{MORB}^{a}$} & \multicolumn{2}{|c|}{ Submarine glasses ${ }^{b}$} & \multicolumn{2}{|c|}{ MORB } & \multicolumn{2}{|c|}{ Submarine glasses } \\
\hline & $\mathrm{RF}^{c}$ & $\mathrm{SF}^{c}$ & $\mathrm{RF}$ & SF & $\mathrm{MF}^{c}$ & SF & MF & $\mathrm{SF}$ \\
\hline 300 & 0.82 & 0.18 & 0.94 & 0.06 & 0.03 & 0.97 & 0.10 & 0.90 \\
\hline 320 & 0.96 & 0.04 & 0.99 & 0.01 & 0.15 & 0.85 & 0.38 & 0.62 \\
\hline 350 & 0.98 & 0.02 & 1.00 & 0.00 & 0.29 & 0.71 & 0.59 & 0.41 \\
\hline 398 & 0.99 & 0.01 & 1.00 & 0.00 & 0.43 & 0.57 & 0.75 & 0.25 \\
\hline 450 & 0.99 & 0.01 & 1.00 & 0.00 & 0.53 & 0.47 & 0.84 & 0.16 \\
\hline 500 & 1.00 & 0.00 & 1.00 & 0.00 & 0.60 & 0.40 & 0.88 & 0.12 \\
\hline 600 & 1.00 & 0.00 & 1.00 & 0.00 & 0.69 & 0.31 & 0.94 & 0.06 \\
\hline 700 & 1.00 & 0.00 & 1.00 & 0.00 & 0.75 & 0.25 & 0.97 & 0.03 \\
\hline 800 & 1.00 & 0.00 & 1.00 & 0.00 & 0.79 & 0.21 & 0.99 & 0.01 \\
\hline 1000 & 1.00 & 0.00 & 1.00 & 0.00 & 0.84 & 0.16 & 1.01 & -0.01 \\
\hline 2000 & 1.00 & 0.00 & 1.00 & 0.00 & 0.93 & 0.07 & 1.05 & -0.05 \\
\hline
\end{tabular}

a Allègre et al. (1987).

${ }^{b}$ Dymond and Hogan (1973).

${ }^{c} R F, S F$ and $M F$ represent rock fraction, seawater fraction and magmatic fraction, respectively.

for MORB (Allègre et al., 1987), and $6.0 \times 10^{-10}$ $\mathrm{ccSTP} / \mathrm{g}$ and 904 for the average of the five submarine glasses tabulated in Table 6 . The effect of seawater dilution on the ${ }^{40} \mathrm{Ar} /{ }^{36} \mathrm{Ar}$ ratio in these magmatic rocks is shown in Table 7. The left column shows values of ${ }^{40} \mathrm{Ar} /{ }^{36} \mathrm{Ar}$ after dilution. The next four columns show the fractions of magmatic rock and seawater required to produce the corresponding ${ }^{40} \mathrm{Ar} /{ }^{36} \mathrm{Ar}$ ratio by direct dilution of the solidified rock. The four columns on the right show the fractions of magmatic source fluid and seawater required to produce these ${ }^{40} \mathrm{Ar} /{ }^{36} \mathrm{Ar}$ ratios prior to solidification.

It can be seen from Table 7 that direct dilution of the magmatic rocks would require only $4 \%$ of seawater contamination to reduce the ${ }^{40} \mathrm{Ar} /{ }^{36} \mathrm{Ar}$ ratio in MORB from 16,700 to 320 . For the submarine glasses of Dymond and Hogan (1973), only $1 \%$ of seawater added to these samples would reduce the ${ }^{40} \mathrm{Ar} /{ }^{36} \mathrm{Ar}$ ratio from 904 to 320 . After solidification, even trace levels of seawater contamination can significantly reduce the ${ }^{40} \mathrm{Ar} /{ }^{36} \mathrm{Ar}$ ratio. For source fluid dilution, the addition of $25 \%$ of seawater to the MORB source fluid would reduce its ${ }^{40} \mathrm{Ar} /{ }^{36} \mathrm{Ar}$ ratio from 16,700 to 700 . For the submarine glasses of Dymond and Hogan (1973), the addition of $25 \%$ of seawater to the source fluid would reduce their ${ }^{40} \mathrm{Ar} /{ }^{36} \mathrm{Ar}$ ratio from 904 to 398. It should come as no surprise that these calculated ${ }^{40} \mathrm{Ar} /{ }^{36} \mathrm{Ar}$ ratios are higher than the measured values in the Kuroko samples. Part of the ${ }^{40} \mathrm{Ar}$ in the MORB and submarine glasses may have been produced by in situ decay of ${ }^{40} \mathrm{~K}$. These samples contain potassium and their ages are not zero. Their initial ${ }^{40} \mathrm{Ar} /{ }^{36} \mathrm{Ar}$ ratio may have been lower than the values used in the above calculations.

Since the ${ }^{129} \mathrm{Xe}$ anomaly in mantle-derived samples is much smaller than the ${ }^{40} \mathrm{Ar}$ excess, it is much easier to be masked by seawater contamination. For example, a $5 \%$ seawater contamination in the MORB source fluid would reduce its ${ }^{129} \mathrm{Xe} /$ ${ }^{130} \mathrm{Xe}$ ratio from 7.4 to 6.6 , which is almost indistinguishable from the seawater value of 6.5 . Therefore, in cases where seawater or sedimentary contamination has occurred, high values of ${ }^{129} \mathrm{Xe} /{ }^{130} \mathrm{Xe}$ are not expected.

In summary, the noble gas abundances of the 18 Kuroko ores are similar to those of igneous rocks (Ozima and Podosek, 1983). The abundance patterns of different types of Kuroko ores resemble that of the mantle. Mixtures of magmatic hydrothermal fluid and seawater for the genesis of the Kuroko ore fluids can account for the noble gas data observed in the Kuroko ores. 


\section{Comparison with other geochemical data}

Many geochemical techniques have been applied to the study of the Kuroko deposits. Fluid inclusions, $\mathrm{H}, \mathrm{O}, \mathrm{S}, \mathrm{C}, \mathrm{Pb}$ and $\mathrm{Sr}$ isotopes, $\mathrm{K}-\mathrm{Ar}$ dating, fission track dating and minor elements have all been studied. We will show below that our results are in agreement with the existing geochemical data.

Fluid inclusions contain the liquid that was in equilibrium with the sample before it solidified. Many fluid inclusion measurements have been carried out on the Kuroko deposits (Watanabe, 1979; Yoshida, 1979; Pisutha-Arnond and Ohmoto, 1983). The temperatures range from $195^{\circ} \mathrm{C}$ to $355^{\circ} \mathrm{C}$ and the salinity is generally between 1 and 8 equivalent weight per cent $\mathrm{NaCl}$. Pisutha-Arnond and Ohmoto (1983) reported a sample (JU79SK19) from the Shakanai deposit with a constant high salinity. Of the 24 measurements carried out on this sample, 13 have salinity higher than 7 equivalent weight per cent $\mathrm{NaCl}$. Such high salinity is difficult to explain in terms of seawater as the sole source for the Kuroko ore fluid since the salinity of seawater is only 3.5 equivalent weight per cent $\mathrm{NaCl}$ while that of magmatic source is usually between 6-8 equivalent weight per cent $\mathrm{NaCl}$.

Hattori and Sakai (1979), Hattori and Muehlenbachs (1980), and Pisutha-Arnond and Ohmoto (1983) dealt with hydrogen and oxygen isotopes of the Kuroko deposits in great detail. The $\delta D$ values range from -5 to -55 per mil, and $\delta^{18} \mathrm{O}$ values range from 5 to -5.5 per mil. The possible sources for the ore fluids are seawater, meteoric water, and magmatic water, or a combination of all these. Ohmoto and coworkers (Ohmoto et al., 1983) suggested that seawater alone was the source of the ore fluids, while Hattori and Sakai (1979) and Hattori and Muehlenbachs (1980) proposed that the ore fluids were a mixture of magmatic fluid and seawater.

Sato and Sasaki (1973), Sato (1975), and Fehn et al. (1983) studied the lead isotopic composition of the Kuroko ores. The isotopic ratios from many deposits are very uniform and show only small variations: ${ }^{206} \mathrm{~Pb} /{ }^{204} \mathrm{~Pb}, 18.23-18.55 ;{ }^{207} \mathrm{~Pb} /{ }^{204} \mathrm{~Pb}$,
$15.42-15.63 ;{ }^{208} \mathrm{~Pb} /{ }^{204} \mathrm{~Pb}, 38.16-38.84$. Sato (1975) reported a regional lead isotopic variation: the lead is less radiogenic from east to west in agreement with the lead isotopic pattern of the igneous rocks in the same area. Most lead isotopic data of Cenozoic and Mesozoic igneous rocks in Japan are very close to the ore leads of the Kuroko deposits (Sato, 1975; Doe and Zartman, 1979; Sato et al., 1981). Fehn et al. (1983) found that although the general ranges of isotopic ratios for the Kuroko deposits are narrow, each deposit has a characteristic isotopic composition and that within the same deposit lead from the yellow ores is usually less radiogenic than those from the black ores. Volcanic host rocks are usually less radiogenic than the ores, while lead in the basement is usually higher in radiogenic lead. Sato (1975) suggested that the ore leads might have a deep-seated origin. Sato $e t$ al. (1981) noted that the ore leads are mostly derived from an igneous source by magmatic differentiation and/or by leaching of solidified magma. They also noted that small additions of lead from the basement rocks were possible. Fehn et al. (1983) suggested that the lead was derived from the volcanics and the basement rocks. However, they pointed out that a partial, or even a total, derivation of the ore lead from a magmatic source could not be ruled out.

Studies of alteration of footwall volcanic rocks of Kuroko deposits revealed that the direction of the fluid flow was from the discharging center toward the outside (Urabe et al., 1983; Fournier and Truesdell, 1973; Green et al., 1983). This pattern of fluid flow would make it difficult to form convective flow to extract metals from the volcanics. The uniform lead isotopic ratios for Kuroko deposits are difficult to explain by the extraction of metal from basement sedimentary rocks (Urabe, 1987), where large variations are observed in lead isotopic ratios. It also seems improbable that the uniform lead isotopic composition in all the Kuroko deposits came from selective extraction of lead only from igneous rocks. The isotopic homogeneity of lead in Kuroko ores and samples closely associated with the Kuroko ores may thus indicate a magmatic origin for these 
metals (Sato, 1975; Sato et al. 1981).

Our conclusion that ore fluids of the Kuroko deposits came mostly from a magmatic source, with some addition of seawater, seems to be in good agreement with the results of other geochemical studies.

\section{CONCLUSIONS}

The different abundance patterns and isotopic ratios of noble gases in the mantle and in the crust can be utilized to identify the material source of terrestrial samples. This noble gas technique has several advantages over other isotopic methods.

The abundances of $\mathrm{Ne}, \mathrm{Ar}$, and $\mathrm{Xe}$ of the 18 Kuroko ore samples are close to those observed in igneous rocks. The abundance patterns of noble gases of these Kuroko ores resemble the Type 2 pattern which Ozima and Alexander (1976) characterized as representing the mantle noble gases. Fissiogenic xenon is observed in the pyrite ores which were formed through the replacement of previously formed minerals by hydrothermal fluid. Calculations based on distribution coefficients and abundances of argon and xenon in Kuroko ores suggest that about $75 \%$ of the Kuroko ore fluid came from a magmatic source, with about $25 \%$ coming from seawater. We concluded that the oreforming fluids of the Kuroko deposits were mixtures of magmatic hydrothermal fluids and seawater with a major contribution from the magmatic source and an inevitable addition from the seawater that was involved in the formation process of the Kuroko deposits. Isotopic ratios of argon and xenon in the Kuroko deposits are almost indistinguishable from those in air and in seawater. The absence of large enrichments of ${ }^{40} \mathrm{Ar}$ and ${ }^{129} \mathrm{Xe}$ may indicate contamination from crustal materials. Further measurements of ${ }^{3} \mathrm{He} /{ }^{4} \mathrm{He}$ of the Kuroko ores and the associated volcanic rocks are desirable.

Acknowledgments-We wish to thank Professor $\mathrm{H}$. Ohmoto of Pennsylvania State University, University Park for providing the Kuroko ore samples used in this study and for sending us the annual reports of the Metal Mining Agency of Japan.

\section{REFERENCES}

Allègre, C. J. and Staudacher, T. (1986) Terrestrial xenology II. Abstr. Japan-U.S. Semin. Terr. Rare Gases, 1-4.

Allègre, C. J., Staudacher, T. and Sarda, P. (1987) Rare gas systematics: formation of the atmosphere, evolution and structure of the Earth's mantle. Earth Planet. Sci. Lett. 81, 127-150.

Barton, P. B., Jr. (1978) Some ore textures involving sphalerite from the Furutobe Mine, Akita Prefecture, Japan. Min. Geol. 28, 293-300.

Bogard, D. D., Rowe, M. W., Manuel, O. K. and Kuroda, P. K. (1965) Noble gas anomalies in the mineral thucholite. J. Geophys. Res. 70, 703-708.

Burbidge, E. M., Burbidge, G. R., Fowler, W. A. and Hoyle, F. (1957) Synthesis of the elements in the solar system. Rev. Mod. Phys. 29, 547-650.

Canalas, R. A., Alexander, E. C., Jr. and Manuel, O. K. (1968) Terrestrial abundance of noble gases. $J$. Geophys. Res. 73, 3331-3334.

Clayton, D. D. (1975) Extinct radioactivities: Trapped residuals of presolar grains. Astrophys. J. 244, L93L95.

DePaolo, D. J. (1988) Neodymium Isotope Geochemistry, Springer-Verlag, $187 \mathrm{pp}$.

Doe, B. R. (1970) Lead Isotopes, Springer-Verlag, 137 pp.

Doe, B. R. and Zartman, R. E. (1979) Plumbotectonics, The Phanerozoic. Geochemistry of Hydrothermal Ore Deposits (Barnes, H. L., ed.), 22-70, WileyInterscience Pubs.

Dymond, J. and Hogan, L. (1973) Noble gas abundance patterns in deep-sea basalts-primordial gases from the mantle. Earth Planet. Sci. Lett. 20, 131-139.

Dymond, J. and Hogan, L. (1978) Factors controlling the noble gas abundance patterns of the deep-sea basalts. Earth Planet. Sci. Lett. 38, 117-128.

Eldridge, C. S., Barton, P. B., Jr. and Ohmoto, H. (1983) Mineral texture and their bearing on formation of the Kuroko orebodies. Econ. Geol. Monogr. 5, 241-281.

Farr, J. E. and Scott, S. D. (1981) Geochemistry of the Uwamuki \#2 stockwork, Hokuroku district, Japan (abstr.). Geol. Soc. Am. Abstr. Prog. 13, 449.

Faure G. (1986) Principles of Isotope Geology, John Wiley \& Sons, 589 pp.

Faure, G. and Powell, J. L. (1972) Strontium Isotope Geology, Springer-Verlag, $188 \mathrm{pp}$.

Fehn, U., Doe, B. R. and Delevaux, M. H. (1983) The distribution of lead isotopes and the origin of Kuroko ore deposits in the Hokuroku district, Japan. Econ. Geol. Monogr. 5, 488-506.

Fields, P. R., Friedman, A. M., Milsted, J., Lerner, J., Stevens, C. M., Metta, D. and Sabine, W. K. (1966) Decay properties of Plutonium-244, and comments 
on its existence in nature. Nature 212, 131-134.

Fournier, R. O. and Truesdell, A. H. (1973) An empirical Na-K-Ca geothermometer for natural waters. Geochim. Cosmochim. Acta 37, 1255-1275.

Franklin, J. M., Lydon, J. W. and Sangster, D. F. (1981) Volcanic-associated massive sulfide deposits. Econ. Geol. 75th Anniv. Vol., 485-627.

Green, G. R., Ohmoto, H., Date, J. and Takahashi, T. (1983) Wholerock oxygen isotope distribution in the Fukazawa-Kosaka area, Hokuroku district, Japan and its potential application to mineral exploration. Econ. Geol. Monogr. 5, 395-411.

Hattori, K. and Muehlenbachs, K. (1980) Marine hydrothermal alteration at a Kuroko deposit, Kosaka, Japan. Contr. Mineral. Petrol. 74, 285-292.

Hattori, K. and Sakai, H. (1979) D/H ratios, origin, and evolution of the ore-forming fluids for the Neogene veins and Kuroko deposits of Japan. Econ. Geol. 74, 535-555.

Hennecke, E. W. and Manuel, O. K. (1975a) Noble gases in lava rock from Mount Capulin, New Mexico. Nature 256, 284-287.

Hennecke, E. W. and Manuel, O. K. (1975b) Noble gases in an Hawaiian xenolith. Nature 257, 778-780.

Hennecke, E. W. and Manuel, O. K. (1975c) Noble gases in $\mathrm{CO}_{2}$ well gas, Harding county, New Mexico. Earth Planet. Sci. Lett. 27, 355-356.

Hoefs, J. (1987) Stable Isotope Geochemistry, Springer-Verlag, $241 \mathrm{pp}$.

Honda, M., McDougall, I., Doulgeris, A. and Clague, D. A. (1991) Possible solar noble-gas component in Hawaiian basalts. Nature 349, 149-151.

Honda, M., McDougall, I., Patterson, D. B., Doulgeris, A. and Clague, D. A. (1993) Noble gas in submarine pillow basalt glasses from Loihi and Kilauea, Hawaii: a solar component in the Earth. Geochim. Cosmachim. Acta 57, 859-874.

Ishihara, S., Kanehira, K., Sasaki, A., Sato, T. and Shimazaki, Y., eds. (1974) Geology of Kuroko deposits. Min. Geol. Special Issue, No. 6, The Society of Mining Geologists of Japan, $435 \mathrm{pp}$.

Ishihara, S. and Sasaki, A. (1978) Sulfur in Kuroko deposits - a deep seated origin? Min. Geol. 28, 361367.

Jeffrey, P. M. and Reynolds, J. H. (1961) Origin of excess $\mathrm{Xe}^{129}$ in stone meteorites. J. Geophys. Res. 66, $3582-3583$.

Lambert, I. B. and Sato, T. (1974) The Kuroko and associated ore deposits of Japan: a review of their features and metallogenesis. Econ. Geol. 69, 12151236.

Manuel, O. K. and Sabu, D. D. (1981) The noble gas record of the terrestrial planets. Geochem. J. 15, 245267.
Metal Mining Agency of Japan (1981) Annual Report of Showa 55, 54-62 (in Japanese).

Metal Mining Agency of Japan (1982) Annual Report of Showa 56, 46-47 (in Japanese).

Metal Mining Agency of Japan (1984) Annual Report of Showa 58, 89-95 (in Japanese).

Ohmoto, H., Mizukami, M., Drummond, S. E., Eldridge, C. S., Pisutha-Arnond, V. and Lenagh, T. C. (1983) Chemical process of Kuroko formation. Econ. Geol. Monogr. 5, 570-604.

Ohmoto, H. and Rye, R. O. (1974) Hydrogen and oxygen isotopic composition of fluid inclusions in the Kuroko deposits, Japan. Econ. Geol. 69, 947-953.

Ohmoto, H. and Skinner, B. J., eds. (1983) The Kuroko and related volcanogenic massive sulfide deposits. Economic Geology Monograph 5, The Economic Geology Publishing Company, 604 pp.

Ohmoto, H. and Takahashi, T. (1983) Submarine Calderas and Kuroko Genesis. Econ. Geol. Monogr. 5, 39-54.

Ozima, M. and Alexander, E. C., Jr. (1976) Rare gas fractionation patterns in terrestrial samples and the earth-atmosphere evolution model. Rev. Geophys. Space Phys. 14, 385-390.

Ozima, M. and Podosek, F. A. (1983) Noble Gas Geochemistry, Cambridge, 367 pp.

Pisutha-Arnond, V. and Ohmoto, H. (1983) Thermal history, and chemical and isotopic compositions of the ore-forming fluids responsible for the Kuroko massive sulfide deposits in the Hokuroku district of Japan. Econ. Geol. Monogr. 5, 523-558.

Podosek, F. A., Honda, M. and Ozima, M. (1980) Sedimentary noble gases. Geochim. Cosmochim. Acta 44, 1875-1884.

Reynolds, J. H. (1956) High-sensitivity mass spectrometer for noble gas analysis. Rev. Sci. Instrum. 27, 928-934.

Reynolds, J. H. (1960) Isotopic composition of primordial xenon. Phys. Rev. Lett. 4, 351-354.

Rowe, M. W. and Kuroda, P. K. (1965) Fissiogenic xenon from the Pasamonte meteorite. J. Geophys. Res. 70, 709-714.

Sarda, P., Staudacher, T. and Allègre, C. J. (1985) ${ }^{40} \mathrm{Ar} /$ ${ }^{36} \mathrm{Ar}$ in MORB glasses: Constraints on atmosphere and mantle evolution. Earth Planet. Sci. Lett. 72, 357-375.

Sato, K. (1975) Unilateral isotopic variation of Miocene ore leads from Japan. Econ. Geol. 79, 800-805.

Sato, K., Delevaux, M. H. and Doe, B. R. (1981) Lead isotopic measurements on ores, igneous and sedimentary rocks from the kuroko mineralization area. Geochem. J. 15, 135-140.

Sato, K. and Sasaki, A. (1973) Lead isotopes of the black ore ("kuroko") deposits from Japan. Econ. Geol. 
68, 547-552.

Sawkins, F. J. (1986) Some thoughts on the genesis of Kuroko-type deposits. Geology in the Real WorldThe Kingsley Dunham Volume (Ins. Min. Metall., ed.), 387-394, London.

Sawkins, F. J. (1990) Metal Deposits in Relation to Plate Tectonics, Springer-Verlag, $461 \mathrm{pp}$.

Staudacher, T. and Allègre, C. J. (1982) Terrestrial xenology. Earth Planet. Sci. Lett. 60, 389-406.

Staudacher, T., Kurz, M. D. and Allègre, C. J. (1986) New noble gas data in glass samples from Loihi seamount and Hualalaii, and in dunite samples from Loihi and Reunion islands. Chem. Geol. 56, 193-205.

Tanimura, S., Date, J., Takahashi, T. and Ohmoto, H. (1983) Stratigraphy and structure of the Hokuroku district. Econ. Geol. Monogr. 5, 24-38.

Tanimura, S., Shimoda, T. and Sawaguchi, T. (1974) On the Fukazawa orebodies, Akita Prefecture. Soc. Min. Geol. Jpn. Spec. Issue 6, 147-156.

Tatsumi, T. and Watanabe, T. (1971) Geological environment of formation of the Kuroko-type deposits. Soc. Min. Geol. Jpn. Spec. Issue 3, 216-220.

Urabe, T. (1987) Kuroko deposit modeling based on magmatic hydrothermal theory. Min. Geol. 37, 159176.

Urabe, T. and Sato, T. (1978) Kuroko deposits of the Kosaka Mine, northeast Honshu, Japan-products of submarine hotsprings on Miocene sea floor. Econ. Geol. 73, 161-179.

Urabe, T., Scott, S. D. and Hattori, K. (1983) A comparison of footwall rock alteration and geothermal systems beneath some Japanese and Canadian volcanogenic massive sulfide deposits. Econ. Geol. Monogr. 5, 345-364.

Valley, J. W., Taylor, H. P., Jr. and O'Neil, J. R., eds. (1986) Stable isotopes in high temperature geological processes. Reviews in Mineralogy 16, Mineralogical Society of America, $570 \mathrm{pp}$.

Watanabe, M. (1979) Fluid inclusions in some Neogene ore deposits in the Green Tuff region, Japan. Min. Geol. 29, 307-321.

Wetherill, G. W. (1953) Spontaneous fission yields from uranium and thorium. Phys. Rev. 92, 907-912.

Yoshida, T. (1979) Fluid inclusion study and oreforming process of the Iwami deposit, Shimane Prefecture, Japan. Min. Geol. 29, 21-31. 